\title{
De Hvide Busser i et sønderjysk perspektiv
}

\author{
Af Henrik SKov KRISTENSEN
}

Omtrent 17.500 fanger blev mod slutningen af Anden Verdenskrig reddet ud af de tyske kz-lejre gennem den såkaldte 'Bernadotte-aktion'. Internationalt anses aktionen, der også kaldes for 'De hvide Busser', for at være svensk, men den havde også et stærkt dansk islæt. Sønderjylland var den landsdel, som blev stærkest berørt af aktionen, og De Hvide Busser udgør en meget væsentlig komponent i den sønderjyske erindring om Besættelsen. Artiklen, der bunder i et af forfatteren tilrettelagt foredrag, beskriver primært, hvordan Sønderjylland og sønderjyder var berørt af aktionen, men også hvordan synet på aktionen har udviklet sig, og om der er baggrund for en justering af hele vurderingen af De Hvide Busser.

I Anden Verdenskrigs sidste måneder blev flere tusinde danske og norske fanger evakueret fra tyske kz-lejre med de såkaldte Hvide Busser. Internationalt er den storstilede operation især kendt under betegnelsen 'Bernadotte-aktionen', fordi grev Folke Bernadotte, som var vicepræsident i Svensk Røde Kors, spillede en fremtrædende rolle. Men aktionen havde også et stærkt dansk islæt, sådan som det er blevet indgående beskrevet i danske fremstillinger. ${ }^{1}$

Det forhold, at Sønderjylland på mange måder udgjorde et knudepunkt i aktionen, er imidlertid ikke blevet særskilt behandlet. Men det var i grænselandet, konvojerne af Hvide Busser blev samlet for at køre til Tyskland for at afhente fanger. Det var her, busserne vendte tilbage til med evakuerede fanger, som dels blev undersøgt og behandlet for sygdomme på karantænestationerne i Padborg og Kruså, dels blev interneret i Frøslevlejren, inden den videre transport til det neutrale Sverige. Og ikke mindst, så var Brundlund Slot i Aabenraa stedet, hvor flere af de ledende svenske, tyske og danske aktører tog ophold og førte delikate og komplicerede forhandlinger om aktionens gennemførelse.

Lokalt, især i det sydligste Sønderjylland, blev De Hvide Busser en meget væsentlig komponent i den kollektive erindring om Besættelsen. Det afspejles tydeligt i antologien, Befrielsesdage i Sønderjylland fra 
1946, hvor De Hvide Busser og ikke mindst karantænestationerne i Kruså og Padborg fylder godt og afspejler en umiskendelig stolthed over den sønderjyske andel i undsætningen af kz-fangerne. ${ }^{2}$

Men holder denne opfattelse for en nærmere prøvelse og den kritiske revision, som faghistorikere de senere år har udsat hele Bernadotte-aktionen for?

\section{Bernadotte på inspektion}

Allerede i juni 1945 udgav Folke Bernadotte sin erindringsbog Slutet, eller på dansk: Sidste akt. Mine humanitære forhandlinger $i$ Tyskland foråret $1945 \mathrm{og}$ deres politiske følger. I bogen, som udkom på fire sprog, og som blev en international bestseller, kommer Bernadotte også ind på sine besøg i Sønderjylland i forbindelse med, at han førte forhandlinger med den tyske SS-Rigsfører Heinrich Himmler, der ud over at være næsthøjest placeret i det nazistiske hierarki også var chef for de tyske kz-lejre. Den 20. april 1945 var Bernadotte til en forhandling med Himmler. Om dette møde skriver Bernadotte:

»Frokostbordet var meget velforsynet, og Himmler spiste med god appetit. Engang imellem slog han med neglene på fortænderne. Efter hvad Schellenberg [som var SS-Brigadeführer og chef for den tyske udenrigsefterretningstjeneste] bagefter fortalte mig, var dette et tydeligt tegn på, at han var nervøs. Denne gang angik samtalen udelukkende de humanitære forholdsregler. Jeg fremførte endnu en gang mit ønske om, at de skandinaviske fanger, som nu var under transport fra Tyskland til Danmark, måtte få tilladelse til at fortsætte til Sverige, og endnu en gang afslog Himmler mit ønske. Schellenberg fortalte bagefter, at Hitler atter havde forbudt enhver indrømmelse på dette punkt.

Umiddelbart efter frokosten afrejste jeg til Friedrichsruh. Efter et hastigt besøg i vort hovedkvarter der, begav jeg mig til Danmark, nærmere bestemt til den lille by Padborg lige nord for den dansk-tyske grænse. Jeg fik der lejlighed til at inspicere de fremragende arrangementer, som de danske myndigheder havde truffet for at kunne modtage og huse fangerne, inden de blev ført videre til forskellige steder i Danmark. Jeg stiftede også bekendtskab med den kendte Frøslevlejr, der lå i nærheden af Padborg. Lejren var overfyldt som følge af de transporter fra 


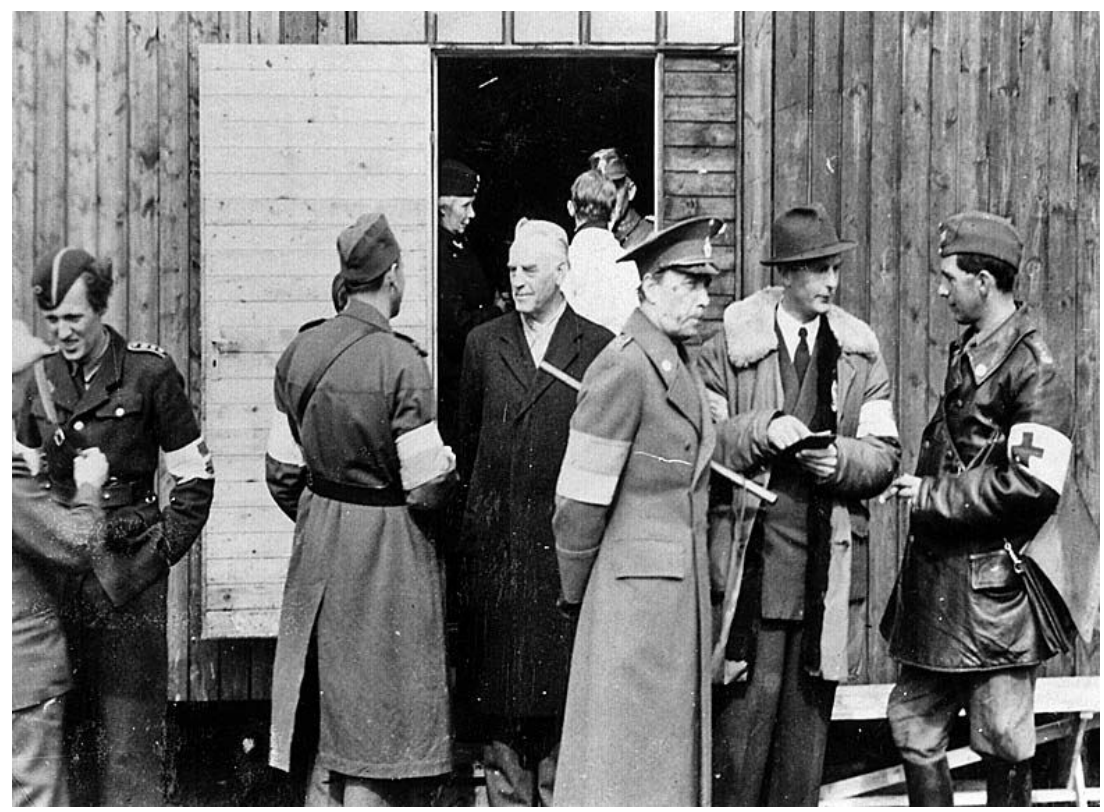

Folke Bernadotte med stok under armen inspicerer karantænestationen i Padborg den 22. april 1945. Bag Bernadotte ses amtmand Refslund Thomsen og yderst til venstre prins Georg i CBU-uniform. Til høire for Bernadotte ses karantænestationens leder, Dr. Krarup og en svensk kaptajn. Foto: Harald Roesdahl i Museum Sønderiylland, Sønderborg Slot.

Tyskland, som vi havde gennemført de sidste dage, men til trods for dette var stemningen høj blandt de norske og danske fanger. [...] 'Du gamla du fria...' - der stod de, alle disse mænd og kvinder, som havde sat deres liv på spil for deres land, og nynnede eller fløjtede den svenske nationalsang. Jeg fik denne oplevelse, da jeg trådte ud på trappen, der førte op til Frøslevlejrens sygebarak - måske den mest gribende oplevelse af alle. Det var en hilsen, der gik lige til hjertet. Disse mennesker var stadig ufrie, men de følte, at friheden lå inden for deres rækkevidde. De vidste mere end vel, hvad der ville ske, hvis den tyske lejrdisciplin satte ind i dette øjeblik. De tog risikoen - de ville vise deres taknemmelighed. De kunne ikke have gjort det på en smukkere måde. $\ll^{3}$ 
Bernadottes inspektion i Frøslevlejren fandt sted den 22. april 1945, netop som hjemtransporterne af norske og danske fanger var kulmineret.

\section{Brundlund Slot}

Bernadotte nævner en passant i sine erindringer, at han den 27. april »tog ind hos amtmand Thomsen « - altså, at han blev indkvarteret hos amtmand Kresten Refslund Thomsen, som havde sin residens og embedsbolig på Brundlund Slot i Aabenraa. ${ }^{4}$

Brundlund Slot var et sted, hvor mange linjer i den hektiske krigsafslutning løb sammen.

Ud over Bernadottes forhandlinger med Himmler om evakuering af kz-fanger foregik der også sonderinger mellem Himmler og Bernadotte om en separatfred med vestmagterne - i høj grad sonderinger, som Bernadotte på skrømt indgik i af taktiske grunde, dels for at kunne fremme hjemtransporten af de nordiske kz-fanger, dels for at kunne fremme en kampløs tysk overgivelse i Danmark og Norge. Walther Schellenberg var stærkt involveret i begge bestræbelser, især som mellemmand, og i forbindelse med sine forhandlinger og rejser til Danmark og Sverige tog også han ophold på Brundlund Slot. Det fremgår af både Bernadottes og Walter Schellenbergs erindringer, men fuldstændig som Bernadotte går han ikke i detaljer med sit ophold på Brundlund. ${ }^{5}$

Også en attaché fra det svenske Udenrigsministerium, Lewenhaupt, tog på Bernadottes opfordring ophold på Brundlund Slot. Her skulle han virke som mellemled mellem Stockholm og Schellenberg via den svenske ambassadør i København, Dardel. ${ }^{6}$ Den svenske regering stod fra februar 1945 bag Bernadottes aktion, formodentlig både af humanitære og storpolitiske grunde. Også fremtrædende danske embedsmænd tog ophold på Brundlund Slot, bl.a. afdelingsleder i Udenrigsministeriet Frants Hvass. ${ }^{7}$

Hele denne storpolitiske aktivitet med kommen og gåen af fremtrædende aktører gjorde naturligvis indtryk på værtsfamilien, amtmand Kresten Refslund Thomsen og hans hustru Ingeborg. Det får man et godt indtryk af gennem Ingeborgs erindringer. Om sit første møde med Bernadotte fortæller hun: 
»I april 1945 - vi troede ikke vore egne øjne, da vi så de hvide busser, men det var jo bestemt sandt, nu hentede de svenske busser danske og norske fanger hjem fra Tyskland. Forældre og koner kørte til Padborg og Kruså, de sad dernede i bilerne hele natten, for bare at få et glimt af deres kære, inden rejsen gik videre til Sverige.

Manden for det hele var greve Bernadotte, ham skulle min mand og jeg modtage i Kruså den 22. april.[...] Det blev middag, inden Bernadottes hvide bil kom farende som et lyn.[...]

Min mand og jeg fulgte med Bernadotte fra Kruså til Padborg-lejren [karantænestationen]. Alle sygeplejersker havde taget opstilling for at byde ham velkommen. D.K.B.-konerne [...] bød maden rundt, Bernadotte greb en hånd, hvor han kunne nå den, og sagde venligt tak.«

Efter frokosten, hvor Ingeborg sad til bords med Bernadotte, kørte de videre til Frøslevlejren, hvor mødet mellem fangerne og Bernadotte gjorde mindst lige så stort indtryk på amtmandinden som på Bernadotte. Og Ingeborg fortsætter:

»Efter en lang og anstrengende dag, der var begyndt klokken seks om morgenen med frokost hos Himmler uden for Berlin, kørte Bernadotte med os hjem, nu skulle han endelig have en rolig nat.

Efter middagen sad Bernadotte hjemme hos os i en god stol, drak en let whisky, og så fortalte han om Himmler. Den mand havde fuldstændig ret, ham der havde skrevet, »at Himmler så ud som en lille nærsynet herre, en skikkelig folkeskolelærer fra landet«.

Himmler var mærkværdig åbenhjertig overfor Bernadotte. »Jeg gør mig ingen illusioner«, havde han sagt, »jeg står øverst på listen, jeg er udnævnt til alle tiders største krigsforbryder, min tid er omme."

Lige så åbent havde Bernadotte svaret, at det troede han også, men tilføjet: »De kan endnu nå at gøre meget godt«.

Bernadotte fortalte om Himmlers gode ånd, Schellenberg, der stod ved Bernadottes side fra først til sidst, og Himmlers onde ånd, Kaltenbrunner, der hadede Bernadotte så åbenlyst, at Himmler havde bedt Schellenberg advare Bernadotte, fordi Kaltenbrunner [som var chef for det tyske sikkerhedspoliti og sikkerhedstjeneste] lod alle hans samtaler aflytte. ${ }^{8}$ 
Bernadotte var altså ret så åbenhjertig over for værtsparret på Brundlund Slot, som på nært hold kunne følge med i hans mange aktiviteter og rejser de følgende dage. F.eks. havde han allerede dagen efter sin ankomst, dvs. den 23. april meget tidligt om morgenen, et møde med Schellenberg ved den dansk-tyske grænse, og endnu samme dag havde han et nyt møde med Himmlers budbringer, denne gang i Flensborg. Og tilsyneladende, hvis man skal tro Ingeborg Refslund Thomsens erindringer, orienterede Bernadotte løbende amtmandsparret om indholdet af sine drøftelser, bl.a. med Schellenberg.

Bernadottes rejseaktiviteter fra Brundlund Slot omfattede også ture til Stockholm og København og i et par tilfælde sammen med Schellenberg ture til Lübeck, hvor man drøftede en tysk kapitulation med Himmler. ${ }^{9}$ Imidlertid skulle drøftelserne med Himmler og alle Schellenbergs anstrengelser i vid udstrækning vise sig at være nytteløse, i hvert fald for så vidt angik den tyske kapitulation, for på grund af Himmlers forhandlinger med Bernadotte faldt Rigsføreren for SS i unåde hos Hitler. I sit testamente pegede Hitler i stedet på storadmiral Dönitz som sin efterfølger.

Efter Hitlers selvmord den 30. april flyttede Dönitz til Flensborg ved den dansk-tyske grænse, og Flensborg blev således tysk regeringsby - og også stedet, hvor vigtige beslutninger vedr. den tyske kapitulation blev taget.

Det kunne være interessant at få forhandlingerne og aktiviteterne på Brundlund Slot belyst nærmere via arkivalsk materiale, men vi er stort set henvist til de publicerede erindringer fra aktørerne. Som det vil fremgå af det følgende, opholdt der sig på Brundlund ledende embedsmænd fra det danske Udenrigsministerium, men deres ophold og virke har tilsyneladende ikke lejret sig i Udenrigsministeriets arkiv. ${ }^{10} \mathrm{Ej}$ heller har amtmand Refslund Thomsen tilsyneladende udarbejdet en redegørelse om begivenhederne til sine foresatte i Indenrigsministeriet - men de førte forhandlinger lå også uden for hans ressort. Han var blot vært. ${ }^{11}$

Forhandlingerne på Brundlund var omgivet af den yderste konfidentialitet, og den danske presse var underlagt censur. Derfor har velunderrettede (især lokale) journalister nok vidst, at der foregik et og andet på Brundlund, men man har ikke været i stand til at formidle noget præcist til samtidens offentlighed. Den 5. maj 1945, altså på selve befrielsesdagen, fremkom der i den lokale avis Hejmdal oplysninger, som havde overordentlig meget for sig, men som også punktvist bar et lettere anekdotisk præg. Det hedder bl.a. i artiklen: 
»[...] Endnu inden ugens udgang var greven tilbage ved grænsen, og på Brundlund Slot. Dette, Dronning Margrethes gamle borg, blev i de følgende timer, hvor man fra alle sider utålmodigt ventede på det tyske sammenbrud, midtpunktet for verdensbegivenhederne. Medens greven pr. telefon forhandlede snart mod nord, snart mod syd, og indimellem fik sig et par timers hårdt tiltrængt hvile, rettedes verdens øjne mod slottet $\mathrm{i}$ Aabenraa, hvorfra greven, der bevarede den strengeste tavshed om sin mission, ved 18-tiden kørte bort, på vej til København. I udlandets radio figurerede grevens tilstedeværelse på Brundlund Slot blandt dagens mest sensationelle meddelelser, som næsten stillede krigsbegivenhederne i skyggen. Mandag aften hed det endog fra London, at greven og Himmler var mødtes på slottet i Aabenraa! Greven var da for længst i gang med nye forhandlinger på Hotel d'Angleterre i København. «12

Journalisten baserede uden tvivl i vidt omfang sin historie på kilder inde fra Brundlund Slot. Det samme gør sig gældende for beskrivelsen i Befrielsesdage i Sønderjylland, hvor journalisten C.J. Bech (som sagtens kunne være forfatter til ovennævnte artikel i Hejmdal) tilføjer lidt kolorit:

»Hen på eftermiddagen [den 28. april] hørte greven sit navn i 'Atlantic'-senderen, der først af alle fortalte nyheden om, hvad der foregik på Brundlund Slot ved »Apenra«. Han tog sig fortvivlet og opgivende til hovedet og troede i første omgang, at spillet nu var slået over ende. Efterhånden som meddelelsen, der havde sin oprindelse i en amerikansk indiskretion, hvad der var greven til trøst, gik sin sejrsgang gennem alle sendere - hvor man så drejede hen, hørte man om slottet $i$ »Apenra «, og det hed sig efterhånden, at også Himmler opholdt sig her - han kom dog mere og mere til den overbevisning, at den store nyhed dog måske kunne komme til at virke fremmende på situationens videre udvikling, idet den af det tyske folk måtte opfattes som et sidste moralsk dødsstød, hvad der jo faktisk også var tilfældet. «13

Men hvorfor var det netop på Brundlund Slot, Bernadotte indkvarterede sig? Ingeborg Refslund Thomsen gør sig nogle tanker om det i sine erindringer. Hun fortæller: 


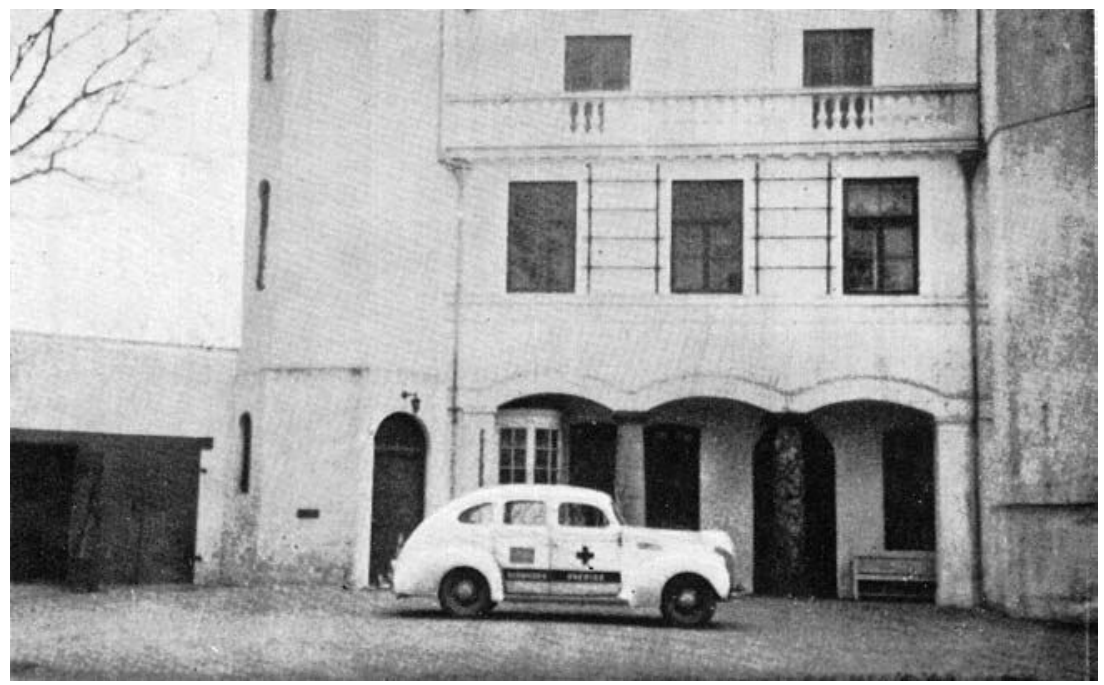

»Folke Bernadottes bil uden for Schönhausen«. Sådan lyder teksten til dette foto $i$ Bernadottes bog Slutet (Sidste Akt). Men bygningen er umiskendeligt Brundlund Slot i Aabenraa, hoor Bernadotte opholdt sig, medens han førte forhandlinger med Himmler i foråret 1945. Foto: Gengivelse fra bogen.

»Mit gode gamle hjem, Brøndlund Slot, var velegnet til at huse og skjule Bernadotte med hans mange telefonsamtaler og gæster. De kom jo altid sydfra, og da slottet ligger i den sydlige udkant af byen, kunne bilerne ankomme ubemærket, og var de først kørt gennem porten, var de skærmet mod nysgerrige blikke. Vore børn var voksne og hjemmefra, og min kloge og varmhjertede Sofie satte en ære i ikke at sige et ord, heller ikke i køkkenet, så var hun på den sikre side.

De københavnske journalister, der ikke kunne spørge om nyt i byen, sagde: "Så må vi have fat i stuepigen! « »Det har vi for længst prøvet", svarede de hjemlige, "Sofie er ikke til at hugge eller stikke i.« For så vidt var jeg tilfreds med Sofie og mig selv, hos os har ingen fremmede så meget som set Bernadotte eller nogen af hans mystiske gæster. ${ }^{14}$

En helt fundamental årsag til, at netop Brundlund Slot kom til at spille en central rolle var imidlertid, at det var amtmandens embedsbolig. Amtmand Refslund Thomsen var nemlig del af det stadigt eksisterende danske embedsapparat. I det hele taget spillede de danske 
myndigheder en langt større og vigtigere rolle i hele hjemtransporten af danske og norske kz-fanger, end Bernadottes erindringsbog giver indtryk af. Faktisk var det sådan, at da Bernadottes bog Slutet udkom i sommeren 1945, drøftede de danske embedsmænd, som havde været involveret i hjemtransporterne, om de skulle tage til orde. Det overvejede de også, da en officiøs svensk redegørelse senere blev udgivet, stort set uden at nævne den danske indsats i evakueringen af de nordiske kz-fanger. Men man enedes om at bide det i sig - ud fra den betragtning, at Sverige havde ydet Danmark store tjenester under den tyske besættelse og ud fra den betragtning, at Bernadotte formodentlig havde spillet en afgørende rolle i hjemtransporterne. ${ }^{15}$

Én fremtrædende dansk aktør, lægen Johannes Holm, udgav dog mange år senere, i 1984, bogen Sandheden om de Hvide Busser, hvor han gør op med den svenske fremstilling, og hvor han i øvrigt tegner et mindre flatterende portræt af Folke Bernadotte. Men ikke desto mindre: internationalt regnes Bernadotte-aktionen eller De Hvide Busser stadig som et svensk anliggende.

I det følgende gives et kort rids af De hvide Bussers oprindelse, og hvordan aktionen forløb, under skyldig hensyntagen til både den svenske og den danske andel i aktionen. Ja, faktisk havde også nordmændene aktier i aktionen. Men først skal der kort redegøres for nogle forhold, som var helt afgørende for, at det besatte Danmark overhovedet kunne spille en afgørende rolle i undsætningen af kz-fangerne.

\section{Særtilfældet Danmark}

En helt klar forudsætning var i realiteten den nu om dage ofte udskældte samarbejdspolitik. Da Danmark og Norge blev besat af Tyskland den 9. april 1940, gav den danske konge og regering, under protest, efter over for det tyske ultimatum og accepterede den tyske besættelse. Til gengæld opnåede man en garanti for, at Tyskland ville respektere dansk »territorial integritet og politisk uafhængighed «, som det hed i det tyske ultimatum. Det betød, at Tyskland, trods besættelsen, der er blevet betegnet som en 'fredsbesættelse', stadig anerkendte Danmark som et uafhængigt land, som Tyskland ikke var i krig med. De danske forfatningsmæssige organer, civile som militære, fortsatte med at fungere efter den tyske besættelse - selvfølgelig med visse begrænsninger, der blev stadig mere udtalte, som tiden 
gik. For selvfølgelig var dansk suverænitet en illusion med en tysk besættelsesstyrke i landet.

De dansk-tyske forbindelser blev varetaget gennem de to landes udenrigsministerier, fuldstændig som normalt. Og Tyskland etablerede ikke sit eget styre i Danmark, modsat i andre tysk-besatte lande.

Efter at den danske regering ophørte med at fungere den 29. august 1943, overtog de ledende embedsmænd i centraladministrationen i realiteten regeringens rolle som forhandlingspartner over for besættelsesmagten. Relationerne mellem de to lande blev fortsat varetaget af de to landes udenrigsministerier, så Danmark forblev det tyske Udenrigsministeriums ressort helt indtil den tyske kapitulation i maj 1945, selv om den tyske værnemagt og det tyske politi i stigende grad blandede sig. Formelt set var Danmark og Tyskland aldrig i krig med hinanden, selv om mange danskere følte, især efter den 29. august 1943, at der i realiteten var en slags krigstilstand.

Norge fik nøjagtig det samme tilbud som Danmark den 9. april 1940, men valgte af flere årsager, som jeg ikke skal gå nærmere ind på her, at afvise det, ligesom i øvrigt Holland og Belgien gjorde det måneden efter. Modsat Danmark valgte alle de tre lande krigen, og alle kom under direkte tysk styre.

Betydningen af Danmarks særstatus i det tysk-besatte Europa kan ikke overvurderes. Den havde afgørende indflydelse på alle forhold i det besatte Danmarks politiske, økonomiske og kulturelle liv. Selv for danske statsborgere i en fjern tysk kz-lejr fik Danmarks særstatus afgørende betydning. ${ }^{16}$

\section{De deporterede}

Næsten 6.100 danskere blev deporteret til kz-lejr eller tugthus i Tyskland. De første massedeportationer fandt sted i oktober 1943, da jøder og kommunister blev deporteret til henholdsvis Theresienstadt og Stutthof. De næste deportationer fandt sted i vinteren 1943-44. De gik til kz-lejren Sachsenhausen, og de deporterede var især de personer, der var blevet arresteret $\mathrm{i}$ forbindelse med urolighederne $\mathrm{i}$ august 1943.

De danske myndigheder, og det vil sige Udenrigsministeriet ved direktøren Nils Svenningsen, protesterede efter hver deportation over for den tyske befuldmægtigede i Danmark, dr. Werner Best. Det gjor- 
de han under henvisning til folkeretten og de tyske løfter fra den 9. april 1940 om at respektere dansk suverænitet, men forgæves.

I januar 1944 foreslog de danske myndigheder over for de tyske besættelsesmyndigheder, at der blev oprettet en lejr på dansk jord, som skulle forhindre deportationer til Tyskland.

Forslaget blev accepteret af tyskerne, og Frøslevlejren blev etableret nær ved den dansk-tyske grænse, og den 13. august 1944 ankom de første 740 fanger til lejren.

Blot en måned senere, den 15. september 1944, brød tyskerne selve grundlaget for lejrens opførelse, da 200 Frøslev-fanger blev deporteret til kz-lejren Neuengamme ved Hamborg. Flere deportationer fulgte, så godt 1.600 Frøslev-fanger blev deporteret til Tyskland. De fleste til Neuengamme, og godt 250 til Dachau ved München.

Beslutningen i marts 1944 om at opføre Frøslevlejren så faktisk ud til at have sat en stopper for deportationerne, men transporten fra Frøslevlejren den 15. september 1944 blev indledningen til en kraftig intensivering af dem. Det næste halve år blev ikke mindre end ca. 5.000 danskere deporteret til Tyskland. Halvdelen var såkaldte 'politiske' fanger, dvs. medlemmer af modstandsbevægelsen. Typisk blev de deporteret 100-200 ad gangen fra Frøslevlejren eller fra Vestre Fængsel i København. Bortset fra en transport til Sachsenhausen i oktober 1944, og som nævnt en transport til Dachau fra Frøslevlejren i februar 1945, gik alle transporter til kz-lejren Neuengamme ved Hamborg.

Andre 2.000 af de deporterede var danske politimænd, som blev interneret, da tyskerne overfaldt det danske politi den 19. september 1944. Via Neuengamme kom politimændene til kz-lejren Buchenwald. Overfaldet på det danske politi ramte også det danske grænsegendarmeri, som bevogtede den dansk-tyske grænse. De ca. 300 tjenestegørende blev interneret i Frøslevlejren. Og to uger senere blev halvdelen af de internerede grænsegendarmer deporteret til Neuengamme.

Endelig var ca. 450-500 af de deporterede danskere såkaldte 'asociale' og 'vaneforbrydere'. De blev deporteret dels fra Frøslevlejren, dels fra Vestre Fængsel i København.

Interneringen og den delvise deportation af de 'asociale' og 'vaneforbryderne' skal ses som et tysk generalpræventivt initiativ i kriminalitetsbekæmpelsen, efter at besættelsesmagten havde sat det danske politi ud af spillet. ${ }^{17}$ 


\section{Hjælpen til fangerne}

Den danske reaktion på de mange deportationer var præget af både chok og vrede. Svenningsen protesterede, som nævnt, over for Best efter hver deportation, og befolkningen sekunderede med en generalstrejke efter den første deportation fra Frøslevlejren den 15. september 1944.

Departementscheferne overvejede alvorligt at kaste tøjlerne, hvilket selvfølgelig ville bane vejen for et tysk styre i Danmark. Især efter at politiet var blevet overfaldet, og det danske samfund dermed var berøvet sin udøvende myndighed, overvejede departementschefstyret at trække sig. Men man besluttede at blive på pladsen og lægge pres på tyskerne, først og fremmest for at undsætte de deporterede så godt som muligt. Ja, det at hjælpe og undsætte de deporterede blev faktisk resten af Besættelsen en hovedbestræbelse for departementschefstyret, hvis bestræbelser kan koges ned til fire punkter.

For det første: at lokalisere de deporterede og etablere kontakt mellem de deporterede og deres pårørende. For det andet: at indsamle information om og inspicere lejre, hvor der sad danskere.

For det tredje: at sørge for at de deportere modtog pakker med madvarer og tøj fra de danske myndigheder. Og endelig for det fjerde, og det var det ultimative mål: at få de deporterede repatrieret til Danmark.

Hvad angik pakker til de deporterede, lykkedes at opnå tysk tilladelse til at sende pakker til alle lejre. Normalt modtog en dansk deporteret tre pakker pr. måned. Enhver, der kender blot en lille smule til forholdene i kz-lejrene, vil kunne forstå, at pakkerne fra Danmark var liv-reddende. Også fordi man med indholdet af dem kunne bestikke sig til store fordele i det bizarre kz-hierarki. Pakkerne gjorde generelt de danske fanger til kz-lejrenes overklasse - ombejlede, misundte og ikke så sjældent forhadte blandt fangerne fra andre nationer, som ikke modtog samme hjælp.

En evakuering fra Tyskland var som nævnt det ultimative mål for de danske myndigheder, men på det punkt løb man længe panden mod en mur. I januar 1944 lykkedes det dog at få løsladt 20 såkaldte 'fejlplacede jøder' i Theresienstadt. De var halvjøder, og deres deportation var en fejltagelse ud fra de kriterier, som tyskerne havde anlagt i Danmark.

Perioden fra oktober til december 1944 markerede et gennembrud, 
og fra begyndelsen af december 1944 til midten af marts 1945 lykkedes det for de danske myndigheder at få repatrieret ca. 500 politifolk og gendarmer og ca. 100 såkaldt 'asociale' og 'vanekriminelle'. Altså hovedsageligt ikke-politiske fanger - som blev ført til Danmark til videre internering i Frøslevlejren.

I midten af marts 1945 trådte hele spørgsmålet om evakuering af deporterede ind i en ny og afgørende fase: Fra nu af blev de danske anstrengelser forenet med de svenske under ledelse af Bernadotte. ${ }^{18}$

\section{Dansk, norsk, svensk initiativ}

Ser vi på hele Bernadotte-aktionens oprindelse, tegner der sig et langvarigt og komplekst forløb, hvor både norske og danske initiativer spillede en afgørende rolle. Der var allerede foregået vigtige forarbejder fra begyndelsen af 1943, hvor den danske kontreadmiral Carl Hammerich arbejdede på at etablere et såkaldt Jyllands-korps af især danske fiskeeksportbiler, der ved et forventet tysk administrativt kollaps kunne hente fanger hjem. Og det var på det tidlige tidspunkt, altså i begyndelsen af 43, norske fanger. Hammerich var norsk gift og stærkt involveret i den danske Norges-hjælp.

I august 1944 mødtes Hammerich og chefen for det danske Socialministerium H.H. Koch med den norske gesandt i Stockholm, N. Chr. Ditleff. Her blev den endelige plan forelagt, og de danske myndigheder bekræftede deres medvirken. Ditleff var gesandt for den norske eksilregering i London, og H.H. Koch fra det danske Socialministerium var manden, som samlede trådene i de danske bestræbelser på at komme fangerne til hjælp - i første omgang med pakkeforsendelser.

Da der samtidig foregik bilaterale norsk-svenske forhandlinger, var et fælles nordisk redningsarbejde i støbeskeen allerede i august 1944.

Tanken om et Jyllandskorps faldt imidlertid på, at Koch vurderede, at planen var for desorganiseret - og ikke mindst på at Hammerich i december 1944 blev arresteret af tyskerne.

Men mange af Hammerichs oprindelige idéer kom faktisk til udførelse med De Hvide Busser.

Da de danske hjemtransporter accelererede fra årsskiftet 1944-45, improviserede det danske Socialministerium et transportberedskab i samarbejde med DSB og Statens Civile Luftværn.

Og de danske erfaringer herfra, og erfaringerne fra pakke- og hjem- 
transporterne, blev stillet til Bernadottes rådighed i marts-april 1945. Det samme gjorde det efterretningsnet, som nordmændene havde opbygget i Tyskland, og som havde indsamlet uvurderlige oplysninger om de norske fangers opholdssteder. ${ }^{19}$

Bernadotte havde, som tidligere nævnt, fra februar 1945 ført forhandlinger i Berlin, bl.a. altså med Rigsfører Himmler, om en overførsel af danske og norske fanger til det neutrale Sverige. Himmler var i første omgang imod en overførsel, derimod så han positivt på, at de nordiske fanger kunne samles i et specielt afsnit i Neuengamme-lejren ved Hamburg under Svensk Røde Kors' opsyn.

Bernadotte tog herpå kontakt til den danske gesandt i Berlin, og begge førte parallelle, selvstændige forhandlinger i Berlin.

Den 12. marts 1945 nåede den første svenske kolonne Nordtyskland, nærmere betegnet godset Friedrichsruh ved Hamburg, som blev hovedkvarter for Bernadotte-aktionen. Den svenske ekspedition bestod af 78 hvidmalede, topmoderne køretøjer: busser, lastbiler, tankvogne og motorcykler. Personellet var værnepligtige, der havde meldt sig frivilligt. Lovlig optimistisk forventede svenskerne, at aktionen kunne udføres i løbet af godt en måned, hvoraf en del allerede var gået med forberedelser i Sverige. Men på grund af manglende erfaring begyndte svenskerne først at samle fangerne i Neuengamme den 24. marts, og en erfaren dansk iagttager på stedet, lægen Johannes Holm, vurderede, at det ville tage svenskerne seks-otte uger og ikke de planlagte ti dage at få samlet fangerne i den såkaldte Skandinaviensafdeling i Neuengamme.

I begyndelse af april vendte ca. halvdelen af det svenske korps tilbage til Sverige, ganske enkelt fordi de frivilliges kontrakt udløb. Den anden halvdel fortsatte, trods kontraktens udløb, det krævende arbejde med at samle fangerne i Neuengamme. Men den svenske indsats var ikke desto mindre blevet stærkt decimeret, og da det samtidig stod klart, at et tysk sammenbrud var nært forestående, rykkede danskerne ind med materiel og personel, som blev stillet til svenskernes rådighed. Et stort antal danske køretøjer, og det drejede sig om offentligt og privat-ejede rutebiler, ambulancer, lastbiler, personvogne og motorcykler kørte til den dansk-tyske grænse, hvor de fik en gang hvid maling, inden de kørte til Friedrichsruh.

Bernadotte, og den svenske regering, krævede, at den samlede operation, altså også den danske del af den, var under hans kommando. Og sådan blev det. Der blev aftalt en svensk-dansk arbejdsdeling: 


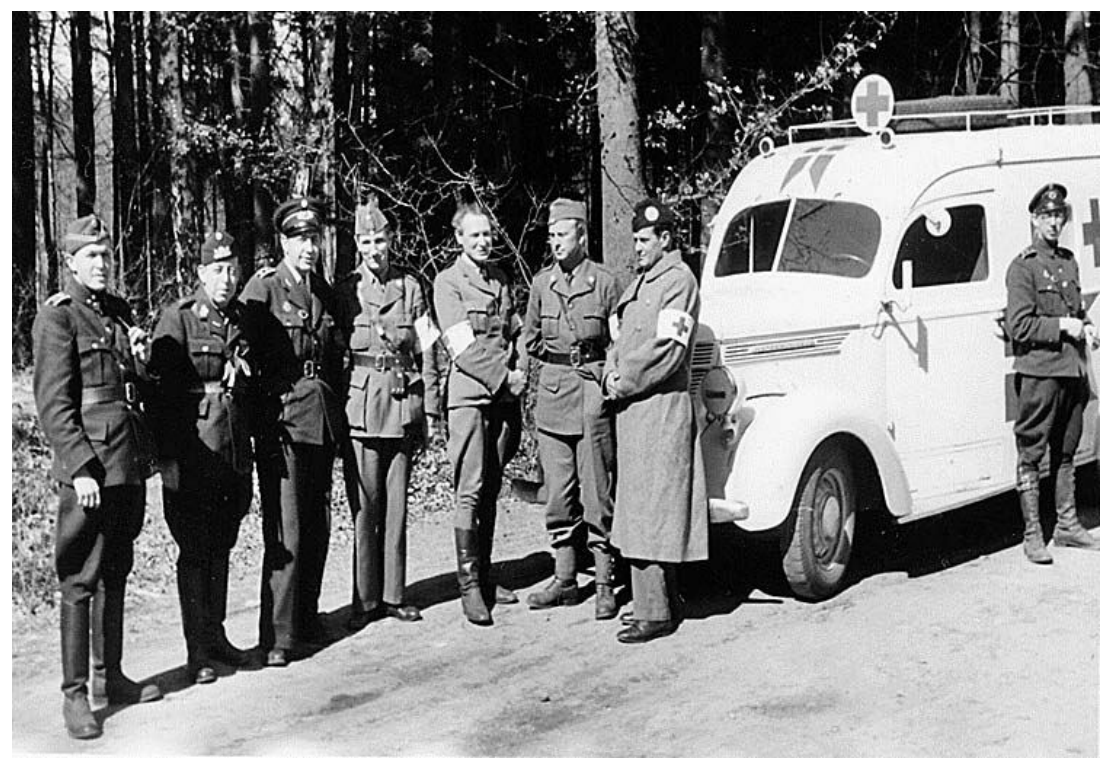

Lxgestaben $i$ Friedrichsruh, der var hovedkvarteret $i$ Tyskland for Bernadotte-aktionen. Fra venstre svenske dr. Volkert, Thune Andersen, Johannes Holm, svenske professor Rundberg, Harald Roesdahl, svenske Hans Arnoldsen og Ernst Trier Mørch. Roesdahl var praktiserende læge $i$ Tandslet på Als og stærkt involveret $i$ De Hvide Busser. Det samme var en anden praktiserende læge, Hans Lorenzen fra Bov, som ikke er på fotoet. Bemærk Thune Andersens 'fastelavnsuniform', som var sammensat af artikler fra en kostumeforretning. Men Thune Andersen bemærkede, at uniformen gav pondus, når han forhandlede med tyske myndighedspersoner. Foto: Harald Roesdahl i Museum Sønderjylland, Sønderborg Slot.

de svenske konvojer, som var udstyret med moderne, benzindrevne køretøjer, opererede fortrinsvis mellem de forskellige lejre og Neuengamme, mens danskerne, som hovedsageligt kun havde gengas-drevne køretøjer, skulle tage sig af transporten nordpå inkl. al forplejning og karantænebehandling.

Den 2. april fik Bernadotte Himmlers tilladelse til, at alle kvindelige fanger samt en del norske studenter måtte føres fra Neuengamme til Sverige, og også de resterende ca. 1.500 danske politifolk, som nu var bragt til Neuengamme, kunne føres nord på.

Senere gav Gauleiter Kauffmann i Hamborg ordre til, at alle skandinaviske fanger skulle føres nordpå, så den 20. og 21. april 1945 hjemførte en nyligt udrustet og hvidmalet armada af danske køretøjer de sidste 4.255 nordiske fanger fra Neuengamme. Den danske armada 
bestod af i alt ca. 123 rutebiler, omkring 30 ambulancer, 18 lastvogne, 12 personvogne, fem-seks motorcykler og ca. 450 hjælpere.

De evakuerede fanger blev i første omgang anbragt dels i Frøslevlejren, dels i den nyoprettede Møgelkjær-lejr ved Horsens. Så da Bernadotte den 22. april besøgte Frøslevlejren og blev hilst med 'Du gamle du fria', var der ikke mindre end 5.500 fanger i lejren.

Den 15. april 1945 var de ca. 400 danske jøder i Theresienstadt, som ikke var omfattet af aftalen om at samle de nordiske fanger $i$ Neuengamme, også blevet afhentet og transporteret til Sverige. Det skete med svenske busser. Som de eneste jøder i det tysk-besatte Europa havde de danske jøder undgået gaskamrene i Auschwitz - igen et resultat af den særegne besættelsespolitiske situation i Danmark. De norske jøder, derimod, blev planmæssigt ombragt i Auschwitz.

Så med undtagelse af de danske kommunister i kz-lejren Stutthof, der var blevet afsnøret af den russiske fremrykning, var stort set alle danske fanger i Tyskland evakueret den 21. april $1945 .^{20}$

\section{Karantænestationerne i Padborg og Kruså}

Modtagelsen ved den dansk-tyske grænse af de reddede kz-fanger var en overvældende oplevelse, sådan som det er fremgået af Ingeborg Refslund Thomsens beskrivelse. Men først og fremmest for fangerne og deres pårørende var det en stærk emotionel oplevelse. Det får man et levende indtryk af gennem sønderjyden Hans Mørups beretning:

»Busserne kører gennem Flensborg og over grænsen ved Padborg. De holder ind på et område ved Padborg station, hvor svensk og dansk Røde Kors har oprettet en modtagelsesstation. Den lange køretur har taget på mine sparsomme kræfter, jeg bliver hjulpet ud af bussen, og halvvejs bæres jeg over i en barak, hvor jeg bliver lagt på en madras.[...]

Og så kommer min egen Ruth [Mørups hustru].[...] Jeg forsøger at stå op, det lykkes med lidt hjælp, og vi får en kærlig omfavnelse. Det har været Guds mening, at vort samliv skal fortsætte. Ruth ser lidt bekymret på mig. Jeg synes nu nok, jeg ser temmelig godt ud, jeg har taget tyve pund på, mens jeg lå på det danske revier [sygeafdeling] i Neuengamme. Men der mangler stadig fyrre pund.[...] 
Lidt efter ankommer mine forældre og min søster Astrid i bil fra Sønderborg.[...] Alt er ufattelig lykke for mig. Vor lille Svend har det godt, han løber rundt på sine små kraftige ben, han er jo næsten 14 måneder nu. Afskeden med Ruth er vemodig, så tæt på hjemmet og så langt bort igen. Men denne gang i sikkerhed.[...]

Der er gjort klar til afgang, den lange række af hvide busser sætter sig i gang. Ruth står rank som et lys og vinker, stadig det samme strålende smil - også i øjnene. Men hvor er hun dog blevet tynd. Det har været en meget svær tid. Først nu fatter jeg til fulde, hvad hun og andre hustruer har gået igennem i disse mange måneder. Angsten og uvisheden om vor skæbne. Visheden om, at vi var hjælpeløse i vore bødlers hænder. Vi kommer gennem Aabenraa, Kolding, Middelfart, Odense og Nyborg. Overalt et hav af mennesker, der vil hilse på os. De har små dannebrogsflag i hænderne. Vi bliver overøst med små gaver og mundgodt, så snart vi gør holdt. Der synges og jubles, man overser de tyske vagter i vognene. På Storebælt får jeg et glas mælk, en kostelig drik, jeg græder af taknemmelighed og udmattelse. «¹

Kruså-Padborg området var et vitalt knudepunkt i hele evakueringen. Her samlede konvojerne sig, inden de rullede mod syd, og her blev de hjembragte indkvarteret, dels, som nævnt, i Frøslevlejren, dels på karantænestationerne i Kruså og Padborg. ${ }^{22}$ På de to karantænestationer, hvor der var bade- og aflusningsfaciliteter, vrimlede det med frivillige fra Danske Kvinders Beredskab, læger, sygeplejersker og personel fra Civilbeskyttelsens Udrykningskolonne, de såkaldte CBU'ere. CBU'erne var også meget aktive i selve konvojkørslen. Livet på karantænestationerne beskrives som nærmest nybyggeragtigt. Nye barakker blev rejst, og der blev arbejdet i døgndrift.

\section{'Breve fra grænsen'}

En af de mange lokale, som hjalp til med at modtage tusindvis af kzfanger i april-maj 1945, var Merete Granzow, som primært virkede ved karantænestationen i Kruså. Hun deltog i dette arbejde som frivilligt medlem af Danske Kvinders Beredskab (DKB), dvs. hun var trænet til at varetage forskellige opgaver inden for forplejning, sygepleje, socialt arbejde og børnepasning. 


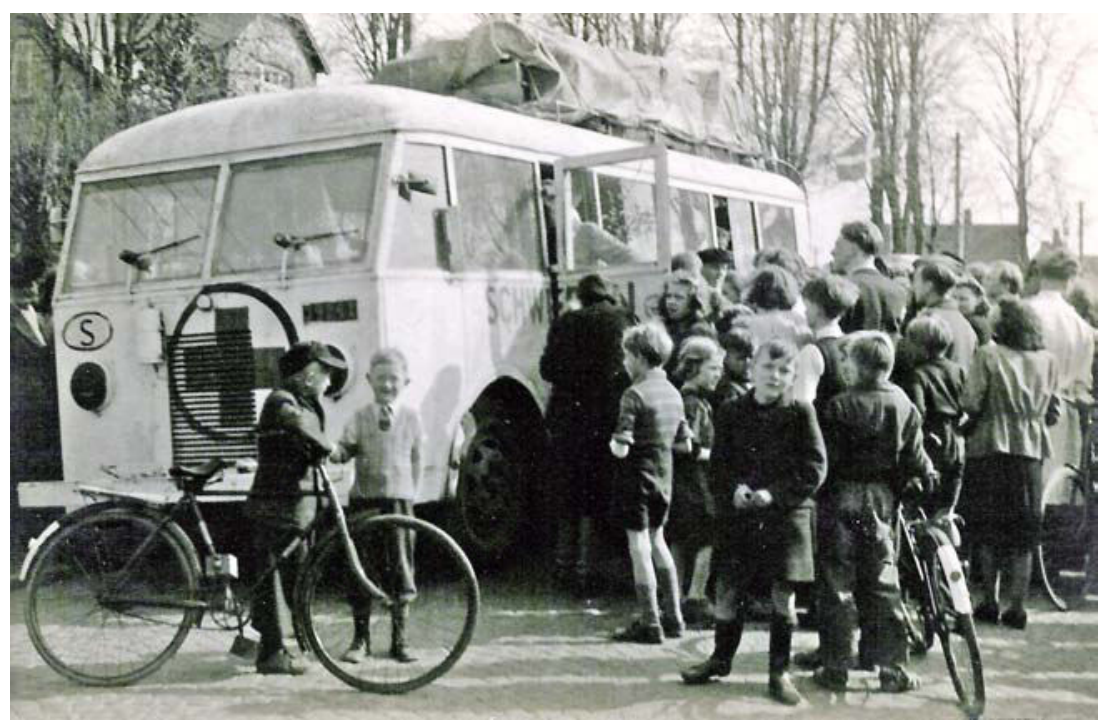

Svenske Hvide Busser har afhentet de danske jøder $i$ Theresienstadt den 15. april 1945 og gør ophold i Haderslev. Foto: Frøslevlejrens Museum.

Merete Granzow var bosat i grænselandet, men stammede fra Aarhus, hvor hun blev født den 8. januar 1919 som datter af cand.theol. og senere lektor på Th. Langs Gymnasium i Silkeborg, Harald Iver Granzow, og Hedevig Granzow, født Schou. Hedevig var formand for Silkeborg Husmoderforening.

Når Merete Granzow bosatte sig i grænselandet, skyldes det formentlig, at hun efter sin læreruddannelse fra Tønder Statsseminarium blev ansat som lærer i Gråsten-Nybøl området.

Modtagelsen af de mange kz-fanger ved karantænestationen i Kruså gjorde et stærkt indtryk på Merete Granzow. Sine indtryk, tanker og forhåbninger har hun fastholdt $\mathrm{i}$ en række samtidige breve til familien fra den 22. april til den 25. maj $1945 .{ }^{23}$

Nybøl, den 22. april 1945

I går havde jeg mit livs største oplevelse: I de sidste dage er der jo gået mange fanger over grænsen og videre til Frøslev[lejren] eller Sverige. De syge, politibetjentene, jøderne og enkelte 'politiske' fanger.

Så hørte vi rygte i forgårs om, at alle danske og norske fanger skulle hentes fra Tyskland. Alle rutebiler var mobiliserede til formålet, og 
mange svenske Røde Kors biler var ankommet. Men da alt var rede, kom der pludselig kontraordre. Himmler havde forbudt det, sagde rygtet. Da rejste Bernadotte sydpå, og ved at gøre al sin indflydelse gældende fik han atter udvirket tilladelse. I løbet af to dage skulle alle fanger være ude af Tyskland.

Fredag morgen $\mathrm{kl}$. fem startede alle bilerne omgående og kørte sydpå. DKB blev mobiliseret ved grænsen, og forplejningsstation [karantænestationen i Kruså] indrettet til at bespise flere tusind danske og nordmænd og svenske chauffører og læger. Da jeg hørte dette, blev jeg klar over, at jeg måtte derned, og da Jefsen skulle derned med øl, kom jeg med plus en hel del andre. Vi nåede til Padborg ved tre-tiden og ventede længe forgæves. Omsider kørte vi videre til Kruså, og der på vejen kom en lang række sygebiler. Vi sprang ud af bilen og vinkede til chaufførerne, og et par syge løftede hovedet og vinkede tilbage.

Da vi nåede forplejningsstationen ved Kruså, var alt spændt forventning. $\mathrm{Nu}$ måtte de raske da snart komme. De pårørende [til kzfangerne] gik og spejdede længselsfuldt ned ad vejen. DKB'ere, læger, sygeplejersker, CBU'ere var parat med alt. Bordene var dækket, og maden færdig. Men timerne gik. Det var bidende koldt, og til sidst kørte vi hjem, noget skuffede. To af lærerne, der var på cykel derned, blev imidlertid til kl. 23.30, og af dem og DKB'erne fik vi at vide, hvordan natten var gået. Kl. ti [kl. 22] kom de første biler endelig, og ude af sig selv af længsel styrtede alle til. Bilerne var tomme! Vel en halv snes tomme biler kørte forbi en lille skuffet flok mennesker. De var havareret undervejs og havde måttet efterlade deres dyrebare last dernede, indtil de kunne blive repareret og atter hente dem.

De næste biler derimod var fyldt med glade nordmænd, der tilbragte natten i Kruså og fortalte mange ting til dem, der var dernede. Det havde været en festlig og uforglemmelig nat, selv om der først ved to-tre tiden kom nogle danske fanger, og da kun ca. 40. Dog, deriblandt var Markussen [formentlig Peter Marcussen, formand for Det unge Grænseværn ] og Damgaard, de to længe savnede fra Gråsten, og inden længe lovede de os, at vi ville få resten af deres landsmænd dernedefra at se. De to lærere havde om eftermiddagen været i Padborg og talt med nogle af de syge fanger. De var forfærdelig medtagne, men enkelte var dog i stand til at tale og fortælle, at ingen beskrivelser af det, de havde gennemgået, var overdrevne.

Da jeg hørte om alt dette, bestemte jeg mig for at cykle derned igen lørdag eftermiddag, og sammen med Annelise Vilstrup og frk. Bak 
startede jeg i bygevejr og skrap modvind. Til vores store undren mødte vi DKB'erne for hjemgående i biler, og da vi nåede forplejningsstationen, var alt tomt. Af nogle CBU'ere erfarede vi, at tyskerne havde forbudt bespisningen, og ingen vidste, om der i det hele taget kom flere fanger. Tunge om hjertet gik vi ned i en restaurant ved grænsen, men snart bredte rygtet sig der, at 1.300 danske og en del nordmænd alligevel var undervejs.

Vi ventede timevis. Denne gang ville vi ikke lade oplevelsen gå fra os. De pårørende stod som en lille frysende gruppe mennesker og ventede og ventede ved de rød-hvide grænsepæle. Mange havde ventet siden gårdagens eftermiddag. Karantænelederen advarede mod snak med fangerne, vinken og mod at vise for megen glæde. Rundt om stod tyske soldater og iagttog os. Tavsheden bredte sig, og minutterne var lange.

Endelig! Næsten inden vi bemærkede det, kom en lastbil kørende. Bagpå sad seks fanger. I fuldkommen stilhed trængtes alle om den; og på én gang var en mand sprunget ned og stod nu og holdt en ung pige i sine arme, der både lo og græd - hun havde fundet sin far. Og nu kom de andre biler. Bil efter bil kørte op og holdt, og strålende glade ansigter kiggede ud og - på én gang lød »Der er et yndigt Land « fra bilerne. »Tys, tys«, blev der råbt. - men en københavner stak hovedet ud og råbte: "Skal vi ikke have lov at synge, når vi kommer hjem til Danmark igen«. Og på én gang var alle forsigtighedsregler glemt. Alle trængtes vi om bilerne, vinduerne blev rullet ned. Der blev vinket, der blev råbt: »Velkommen «, og ivrige hænder raktes ud og blev trykket til velkomst. Og stadig hørte man jubelråb, når der blandt de mange blev fundet en broder, en søn, en ven, en far eller en ægtemand [...].

Det var strengt at se bilerne køre igen, og hænder, der næsten ikke kunne slippe hinanden, blive tvunget fra hinanden, men de, der blev tilbage, strålede dog, som havde de oplevet et under, og alle vi andre blev smittet af deres glæde.

Og det blev ved! Ustandseligt kom bilerne kørende, og gladere og gladere blev velkomstråbene: »Velkommen hjem«, »Velkommen til Danmark«. Det var som vore kæreste venner, der vendte tilbage. Aldrig vil jeg glemme de mange varme håndtryk, jeg fik, og alle de glade stemmer, der råbte: »Tak, tak «, når jeg løb hen til vinduerne og råbte: »Velkommen«. Alle hæmninger og bånd var brudt - det var det, der var det vidunderlige - ingen tænkte på andet end at give frit 
udtryk for den glæde, varme og kærlighed, han gennemstrømmedes af. »Vi har ventet jer så længe«. »Vi har tænkt så meget på jer«. »Tak for hvad I har gjort for Danmark«, lød det mellem mennesker, der aldrig havde set hinanden før [...].

I det hele taget så de fleste [hjembragte fanger] raske og glade ud. De fortalte, at de sidste ti dage under svensk pleje i Neuengamme havde betydet en hel genfødelse. Ellers havde det været strengt. »Det er jo ikke de bedste hoteller, de har dernede«, lo en københavner [...].

Der var mange biler med lutter nordmænd, og vi opdagede snart, at de færreste havde tid til at ofre dem nogen videre opmærksomhed. Derfor var vi nogle stykker, der koncentrerede os om nordmændene og det fortrød vi ikke. De var så lykkelige over at tale med os og trykke vore hænder og blive hilst velkommen af danske piger. »Tak, tak «, »Tak for den strålende velkomsten!«. »Her er koldt i Danmark, men hjerterne er varme!«, lød det fra dem. De var så pragtfulde at snakke med. Mange havde været dernede i fire år og intet hørt hjemmefra. ${ }^{24}$ Men alle var fyldt med mod og håb og en inderlig kærlighed til Danmark og Sverige, hvis Røde Kors pakker havde holdt liv i dem: »Uden jer var ikke én af os kommet hjem«. »Det skal vi aldrig glemme jer«, blev de ved at sige. Mange sagde: »Vi troede aldrig, vi skulle komme hjem mere $[$ [...].

Sommetider holdt jeg op med at snakke og gik blot langs bilerne og vinkede og smilede og så ind til dem, og det var næsten det allerbedste. Jeg vil aldrig glemme de strålende øjne, der smilede til mig, og som sagde mere, end ord kunne udtrykke. I sådanne øjeblikke strømmede der en sådan kærlighed og glæde imellem os, at det kan gøre helt ondt i mig af varme og lykke, når jeg tænker på det. For det var jo vore soldater, vore helte, der i hverdagens kår havde givet deres liv for vor fremtids skyld. Og hvor har deres skæbne i disse år ligget som en byrde over os, altid, selv i de lyseste stunder. Derfor var det et helt under at se dem så glade og lykkelige og at kunne få lejlighed til at sige dem tak.

Og mine tanker sprang pludselig tilbage til den 9. april 1940, da vi var tavse tilskuere til tyskernes [den tyske mindretalsbefolkning i Sønderjylland] begejstring, da bil efter bil med tyske soldater rullede ind i Tønder. ${ }^{25}$ Dette var oprejsningen. Hvor var dette dog trods alt forskelligt. Tyskernes begejstring var så støjende, så overmodig og fanatisk, her var alt så enkelt, ingen blomster, ingen store ord, ingen fraser, kun stilfærdig, inderlig glæde og kærlighed. I to timer passere- 
de bilerne forbi os, og $\mathrm{i}$ to timer levede vi i en anden verden, en verden, hvor der kun var taknemmelighed og varme, lykke og kærlighed. En sidste vinken, et sidste håndtryk, så forsvandt de lysende og varme øjne, de løftede hænder, og der blev stille blandt de mennesker, der stod tilbage. En far og en mor sagde bedrøvet: "Så fik vi ikke vor søn at se«. De andre begyndte at gå, og vi mærkede pludselig, at vi var gennemisnede af blæsten og våde af utallige regnbyger.

Ad grå og våde veje gik det først til Gråsten, så for mit vedkommende til Nybøl, hvor jeg fik luft for noget af det, der fyldte mig. Hele natten har jeg drømt om det, og nu i dag ser jeg det hele for mig bestandig og hører endnu stemmerne i mine øren [...].

Nej, det onde har ikke sejret. Den 21. april var den første forjættelse om:
Vælden, der glipper, om duen, der slipper af ørnens klo, om freden, der kommer med stordåd og sang, med sol og skærsommer i Danevang. ${ }^{26}$

Gråsten, den 24. april 1945 Jeg må skrive til jer igen. Jeg trænger sådan til det for at få lettet nogle af mine tanker, selv om jeg er forfærdelig træt.

Jeg er lige kommet hjem fra grænsen, hvor jeg det sidste døgn har været med DKB i gang med forplejningen af 450 franske kvindelige fanger fra en koncentrationslejr. Det var så forfærdeligt. Jeg kan slet ikke forstå, at det ikke blot er en ond drøm, når jeg tænker tilbage på, hvad de fortalte. Jeg vil slet ikke fortælle jer det i enkeltheder, men I skal dog vide, at intet, hvad man har hørt, er overdrevet; tortur, umenneskelige straffe, hungersnød, mishandling hørte til dagens orden, og hver uge blev de uarbejdsdygtige sorteret fra og sendt til gaskamrene, hvor i forvejen tusinder af børn og gamle var aflivet, for senere at brændes i krematorierne, hvis stank forpestede luften. Og mishandlerne og opsynsmændene var foruden SS-mændene ganske unge piger mellem 16 og 20 år, der uden barmhjertighed pinte deres medsøstre til døde.

K1. 11 om formiddagen ankom de første seks biler, og en flok men- 


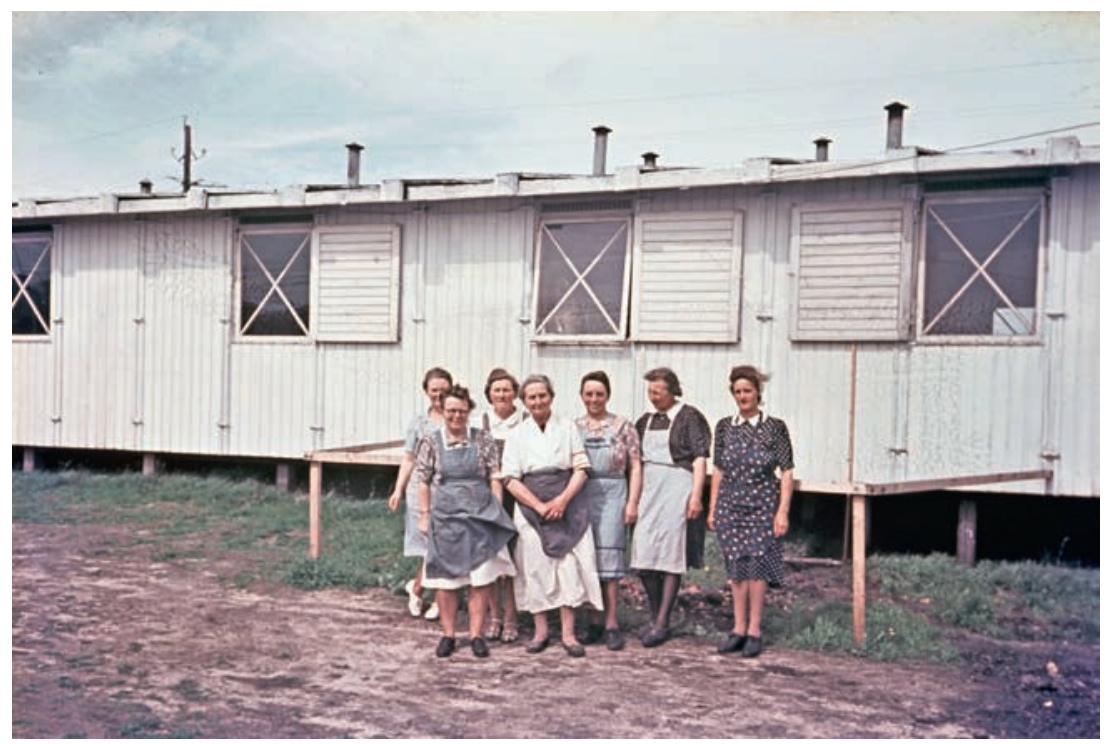

Frivilligt køkkenpersonale på karantænestationen i Padborg. Sammen med frivillige fra Danske Kvinders Beredskab arbejdede de i døgndrift fra den 20. april til den 4. maj 1945. Foto: Frøslevlejrens Museum.

nesker begyndte at vandre op mod os, dødtrætte, vaklende kvinder i alle aldre i stribede fangedragter; slæbende på nogle elendige, snavsede bylter. Flere var syge og kunne ikke støtte på benene, men måtte med bilen sendes videre til sygeafdelingen. Vi løb dem i møde fra baraklejren og hilste dem 'bon jour' og 'velkommen' og forsøgte at forklare dem, at de var blandt venner nu, men de så blot så elendige og triste ud, at det var til at græde over. Først da de var blevet vasket - og hvor de vaskede sig! - og kom ind i spisesalen, hvor vi havde maden parat, klarede deres ansigter op, og mere og mere strålede deres øjne, da vi løb rundt med mad og fyldte tallerkner. Salen genlød af lovord og takkeord, taknemmelige hænder raktes frem mod os, og de begyndte at fortælle om alt det forfærdelige, de havde gennemgået.

De var flest politiske fanger, anklaget for at have været med i modstandsbevægelsen, hjulpet flygtninge, skjult sabotører, eller blot været i familie med undslupne sabotører. Også en del kommunister og jøder var iblandt dem. Nogle var simpelt hen blot blevet bortført fra en erobret by, - samtlige kvinder i byen - og endelig var der en del 
forbrydersker, dem, tyskerne kalder 'asociale elementer'. Der var alle aldre, fra 16 til 70 år og fra alle samfundslag, selv de allerhøjeste. Mange var meget smukke, trods lidelserne, der havde præget dem, og mange meget kultiverede og tiltalende. Men fra dem alle lød jamrende, fortvivlede ord om det Helvede, de havde forladt, mange græd og græd, når de fortalte derom, andre var helt forstenede, og atter andre fuldkommen knækkede og nedbrudte [...].

Der var en ung danserinde, hvis ben var blevet ødelagt ved mishandling, som jeg talte så meget med. Også en ung student, en henrivende ung pige, charmerende og intelligent, der studerede filosofi. Men selv om vi skulle vise dem et glad ansigt, var det umuligt at lade være med at græde med dem - og jeg kommer hele tiden til at græde, når jeg tænker på dem og deres skæbne.

Efter middagen hvilede de i sovebarakker, hvor der var halm og tæpper, og hen på eftermiddagen, da de kom ud i det fri, så de fleste meget bedre ud.

Ved seks-tiden [18-tiden] blev der pludselig travlhed. 22 store Røde Kors biler kom kørende, og de først ankomne jublede og pegede: »voila, ici nos camarades! « Vi styrtede ned for at modtage dem, og tænk - da lød Marseillaisen [den franske nationalhymne] os i møde fra de trætte og udslidte, men lykkelige passagerer. Igen kunne vi næsten ikke holde tårerne tilbage. Hvor var det vidunderligt at se deres møde med kammeraterne, der stod og ventede og jublende råbte til dem: »Vi er blandt venner «, »vi er i Paradiset«, »det er som en drøm «, og meget andet lykkeligt og taknemmeligt, som vi ikke forstod. De kastede sig i hinandens arme og smilede og græd og jublede over atter at være sammen, ude i friheden. Og da de var vasket og med de andre kom ind til aftensmad! Åh, aldrig havde jeg troet, man kunne se så megen lykke og taknemmelighed strålende fra menneskers ansigter. De strakte ustandseligt hænderne ud, greb fat i os, knugede vore hænder, blev ved at takke os og se os ind i øjnene med deres strålende blik. »Merci!«, »merci beaucoup! « Men mange kunne ikke spise for tårer. En gammel kone sad og hulkede og blev ved at sige: »C'est un rêve!« [det må være en drøm!], »Ce n'est pas vrais!« [det er ikke sandt!]. Åh, de stakkels små menneskebørn! Åh, kunne man dog give dem alle kræfterne og livsmodet tilbage; det var næsten ikke til at udholde at se [...].

Op ad formiddagen [næste dag] skulle de afsted, videre til Sverige. Men de ville slet ikke fra lejren: »Vi vil ikke forlade Danmark«. »Dan- 
mark har reddet os!«.»Vi vil aldrig glemme jer dette!«. Den ene efter den anden kom hen til mig og gav mig hånden, og en sagde: »Aldrig kan vi takke jer nok herfor. Vi kan ikke udtrykke, hvad vore hjerter er fyldt af. I har givet os livet tilbage."

Vi stod alle på trappen, da de gik forbi os ned til vognene, og det billede vil jeg aldrig glemme. De elendige skikkelser i stribede fangedragter med fangenumre tatoveret på armen og hærgede ansigter, men alle med strålende, strålende mørke øjne og vinkende hænder, og deres »merci «, »merci«, der lød fra hver eneste. Nogle løb hen til os og kyssede os på begge kinder, og tårerne trillede os ned ad kinderne, men de andre græd ikke, de var kun jublende lykkelige og taknemmelige [...].

I de næste dage kommer 15.000 kvinder af alle nationaliteter fra denne lejr. Mændene er ikke frigivet. Jeg tager sikkert derned [til karantænestationen i Kruså] i bededagsferien og sender afbud til Frandsen. Jeg kan ikke tænke mig at male og snakke og hygge, hvis der er brug for mig dernede, og det er så vidunderligt at hjælpe.

Svenskerne er storartede. De trodser alle farer på turen, ild fra fronten, bombardement osv. Vi kan takke Sverige for meget.

Den 1. maj 1945

Jeg må stadig skrive brev til jer, for bestandig oplever jeg nye mærkelige ting, og hvis jeg ikke straks får det fortalt, fortrænger det ene det andet. Det er blot så svært at finde de rigtige ord. I grunden kan det slet ikke siges med ord, og det er næsten synd at prøve derpå, men det er dog så vidunderligt at dele alt med jer.

I søndags kl. syv om aftenen blev vi med halvanden times varsel igen kaldt til grænsen. Der var kommet bud, at 4.000 polske kvinder var undervejs. Erika var heldigvis hos mig, så vi kunne atter følges ad. Også fru Jefsen og flere af lærerinderne var med. Vi arbejdede det meste af natten med at smøre brød til de 1.000, der skulle bespises i Kruså, resten i Padborg [hvor der også var etableret en karantænestation], og hele natten ventede vi dem. Det blev kun til halvanden times søvn. Først ved fem-seks tiden begyndte bilerne at komme med en flok udmattede kvinder, der havde været undervejs en uge - uden brød! De havde levet af Røde Kors konserves, men dette var langtfra nok.

Og så fulgte den samme underfulde forvandling med dem, takket være mad og varme og venlige ord, fra en flok hærgede, sky mennesker til lykkelige, taknemmelige og strålende kvinder. Men disse hav- 
de noget over sig, som ikke kan udtrykkes, men som gør, at vi alle er kommet til at elske Polen og dets folk. De var alle politiske fanger altså frihedskæmpere. Selv sagde de, at de repræsenterede det, man på russisk kalder »intelligensen «. Og de var intelligente, oplyste, højt kultiverede, men samtidig havde de en så vidunderlig indre rejsning og skønhed, en så sjælelig dybde, at vi var helt betagede. De smilede nok strålende, men dog ikke så strålende som de franske; der var et tungsind og en vemod over dem, der måtte gribe os alle. Deres væsen var roligt, behersket og afklaret - de fortalte kun lidt om deres lidelser og ikke med affekt som franskmændene, de takkede os, men på en anden måde end de følelsesbetonede franskmænd; de havde færre tårer og klager, men deres tungsindige øjne fortalte om mere. De polske jøder forleden sloges som ulve om maden, tiggede og bad om mere brød. Disse ventede stille og tænkte alle på hinanden. Ingen søgte at lyve sig til mere.

Men hvor havde de lidt! Den tortur og mishandling, de havde været udsat for i lejren, kan slet ikke beskrives [...].

Åh, jeg vil ikke fortælle mere. Mit hoved er fyldt med rædselsberetninger, men over det hele stråler mindet om disse kvinders storhed $\mathrm{i}$ lidelsen. - Jeg har endnu ikke hørt nogen fortælle, at de har hørt hadefulde ord fra dem. Jeg har selv hørt utallige beviser på det modsatte. Gestapo er hadet. Men den enkelte tysker: De trækker undskyldende på skulderen - vildledt! Vi spurgte en om Polens indstilling til tyskerne efter krigen. Hun svarede: »Jeg er katolik, og min tro forbyder mig at hævne! «

[...] Vi traf så mange vidunderlige mennesker, sygeplejersker, studenter, lærerinder, officershustruer og to pragtfulde gamle damer søstre - godsejersker med en rejsning og en intelligens og en adel over sig. De så mørkt på Polens fremtid og var bange for russerne. Det var i det hele taget den typiske indstilling.

Men vor største oplevelse var seks unge piger - studenter, folkeskolelærerinder og en gymnasielærerinde. Dem glemmer vi aldrig. Vi gik tur med dem og sad om eftermiddagen og snakkede så meget med dem. De var helt på bølgelængde med os. Samme interesser, samme idealer, samme kærlighed til ånd, de kendte og elskede Dostojewski, Tolstoi, Gandhi, Goethe, H.C. Andersen, Ibsen osv. Og så havde de dette gribende, smertefyldte og afklarede over sig, som fyldte os med andagt og ærefrygt. Livet var for dem for evigt forvandlet, deres personlige livsglæde var slået i stykker, men de ejede mod, håb og tro 
på sandheden, og de ville leve livet for deres lands og deres idealers skyld. De sang for os derinde i barakken, hvor de lå i halmen og hvilede, og på én gang opfordrede de alle de andre til at synge deres nationale hymne og bøn og derefter deres nationalsang. Alle de syge og trætte rejste sig med dem. Hele barakken var på én gang fyldt med andagt, og så lød et brus af højtidsfulde stemmer - en vidunderlig hymne og bøn. Bagefter fulgte så nationalsangen, som vi nu allerede kendte fra dagene før [...].

I dag er det svært at leve normalt. Begrebet 'menneskelig lidelse' har pludselig fået indhold og er trængt så stærkt ind på os. Det bliver svært igen at være sorgløs. Polens, Hollands, Belgiens, Frankrigs skæbne vil ligge os så stærkt på sinde, og al uret og lidelse vil gøre så ondt. Og tanken på alle dem, de endnu sidder i lejre eller færdes på landevejene, forfølger os stadig [...].

Gråsten, den 28. april $1945^{27}$

Trods alle rædslerne har disse bevægede dage dog styrket min tro på livet, min optimisme, fordi det har været dage båret oppe af og gennemlyst af den dybeste kærlighed, hengivenhed og taknemmelighed. Og det har været liv! At hjælpe, at sprede lys, at give mad til de sultne og opmuntring til de triste og ængstelige - der er intet større i livet!

De sidste dage har det været polske jøder samt nogle hollændere og belgiere, som vi har taget os af. Disse polske kvinder var vidt forskellige fra de franske indtagende, livlige og charmerende kvinder. Disse var tungere, mere indesluttede, tungsindige og vemodige, også ret primitive. De var vilde efter mad, nogle var som dyr. I seks år havde disse været fanger og sultet og lidt. De fortalte os om de samme rædsler som franskmændene, dog havde disse åbenbart bedre kunnet udholde dem, thi de fleste så noget bedre ud. Værst var det, når de fortalte os om de forfærdelige videnskabelige forsøg på levende mennesker - og om gaskamrene, hvor de alle havde mistet deres børn.

Carla Schibler [en lokal højskole-kvinde og ledende skikkelse inden for Det Unge Grænseværn] var med, og hun var enestående Efter at de havde spist - ude i øsende regn! (de var så mange, så vi måtte bespise dem ude, og regnen styrtede ustandseligt ned), kom der et tidspunkt, hvor de ikke længere kunne sove, men skulle underholdes. Da fik Carla Schibler dem til at synge, og på én gang var disse menne- 
sker som forvandlede. De glemte alle deres sorger og tårer og gav sig hen i sangene, vemodige flerstemmige sange. Vi sang 'Der er et yndigt Land' for dem, og da kom én hen imod os og spurgte med spændt forventning, om det var forbudt at synge deres polske nationalsang, som de ikke havde sunget i seks år.

Jeg vil aldrig glemme, da disse hundreder af mørkøjede kvinder sang deres fædrelands sang, mens tårerne trillede dem ned ad kinderne, og mange ikke kunne synge for bevægelse. I flere timer blev de ved med at synge, og rørende nok sang de også med glæde tyske sange og viser. De talte alle udmærket tysk, så vi fik snakket en masse med dem. De var alle frihedskæmpere, og da de blev ved at takke os, måtte jeg sige dem, at det var os, der skyldte dem tak, thi de havde kæmpet for vor skyld, og uden deres kamp og lidelse var freden og sejren ikke så nær, som den er nu.

En del var for resten også Jehovas Vidner, taget fordi de ikke ville skrive under på en fornægtelse af dette - og nogle havde med fare for tortur gemt deres bibel i støvlerne eller på brystet i alle disse år. Deres tak over maden var så ubeskrivelig. Alle de lovord, der lød, taksigelser og velsignelser og lykkelige blikke - åh kunne I blot opleve et sådant øjeblik. Det er Paradis på jorden. Og så omsider i går kl. 5 [om eftermiddagen] var alle biler rullet væk og lejren tom efter $i$ en uge at have rummet $i$ tusindvis af taknemmelige mennesker fra seks nationer. Og vi - DKB'erne, CBU'erne og sygeplejerskerne samledes i en tom barak til aftensmad. [...] Vi føler, at vi sammen har oplevet historiens begivenheder; vi er kommet disse lande så nær, at deres skæbne altid vil ligge os på sinde; vi har oplevet menneskelig lidelse i en sådan grad, at vi aldrig vil kunne tage vore egne småbekymringer nær, og vi er blevet så dybt forbundet med vore lidende medsøstre og -brødre, at det bestandigt vil ligge som en smerte i vort sind.

Og dog har vi oplevet kærlighedens og godhedens sejr. Thi det, der lyste ud af disse menneskers øjne, var aldrig had og hævn, men altid taknemmelighed og hengivenhed. Tænk, ingen af os har hørt ét hadets ord! Jeg er kommet til at elske de hvide biler med de røde kors, de svenske chauffører, der har trodset bomber og kugler for at hjælpe, og de stilfærdige unge søstre [sygeplejersker], der gik så stille og mildt mellem fangerne.

Der døde en fransk kvinde forleden. Hendes to døtre var hos hende, og hendes sidste ord var: »Liberté!« Frihed! Disse dage har lært os, hvad frihed og kærlighed betyder. 


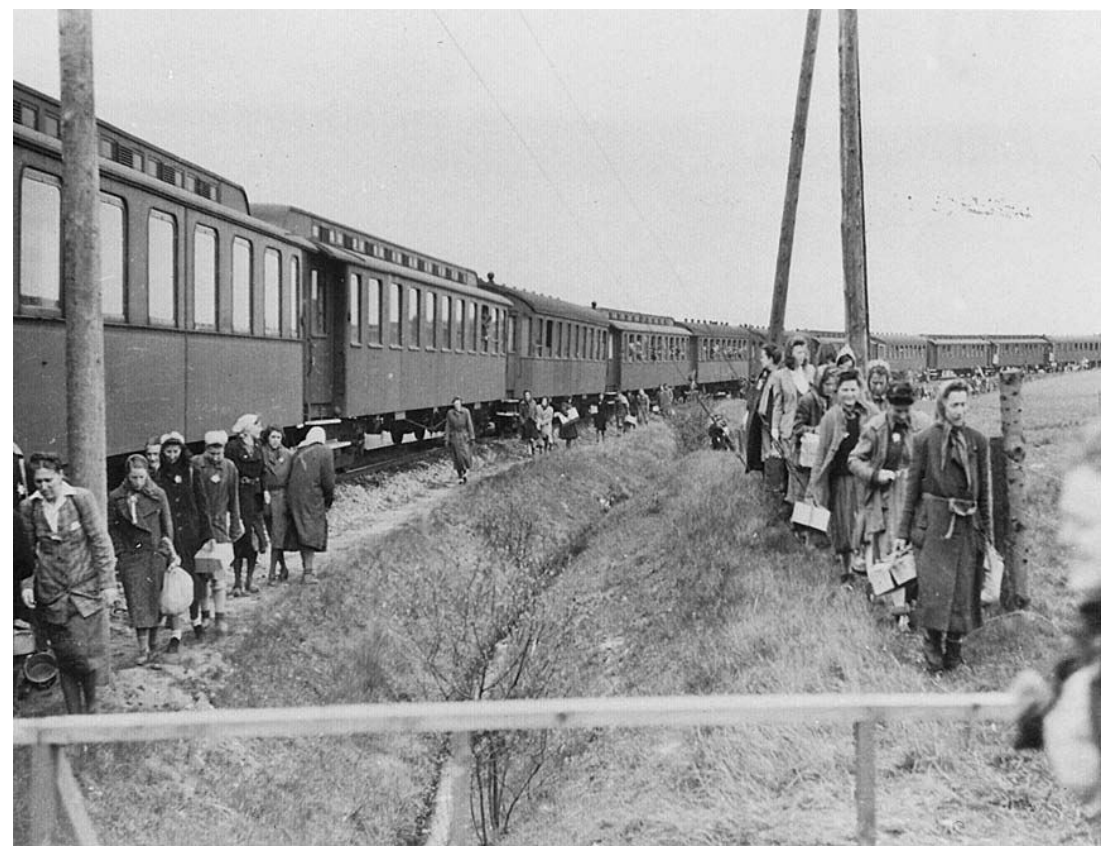

Kvindelige fanger fra kz-lejren Ravensbrück ankommer med tog til Padborg, hvor de bliver underbragt, bespist og behandlet på karantænestationen, inden de bliver transporteret videre med tog til det neutrale Sverige. Bemærk at flere af fangerne er jøder, idet de bærer den gule Davidstjerne. Foto: Frøslevlejrens Museum.

\section{Stjernestund eller pagt med djævelen?}

Merete Granzows samtidige breve om sine oplevelser som frivillig hjælper ved karantænestationen efterlader et stærkt indtryk af solidaritet, empati og fællesskab med de udfriede kz-fanger, som kom fra allierede nationer. Hendes breve (der sikkert for en nutidig læser forekommer højstemte, ja altmodisch i tonen) gennemstrømmes af beundring over såvel hjælpernes indsats som den måde, hvorpå kz-fangerne kommer overens med deres hårde skæbne på.

På den baggrund forstår man, at Bernadotte-aktionen, eller De Hvide Busser, almindeligvis berømmes som en helt bemærkelsesværdig aktion, hvor det gode besejrede det onde. Aktionen har været med til at profilere Sverige som en neutral og humanitær nation, og når en svensk statsminister i 2014 karakteriserer Sverige som en »humanitær 


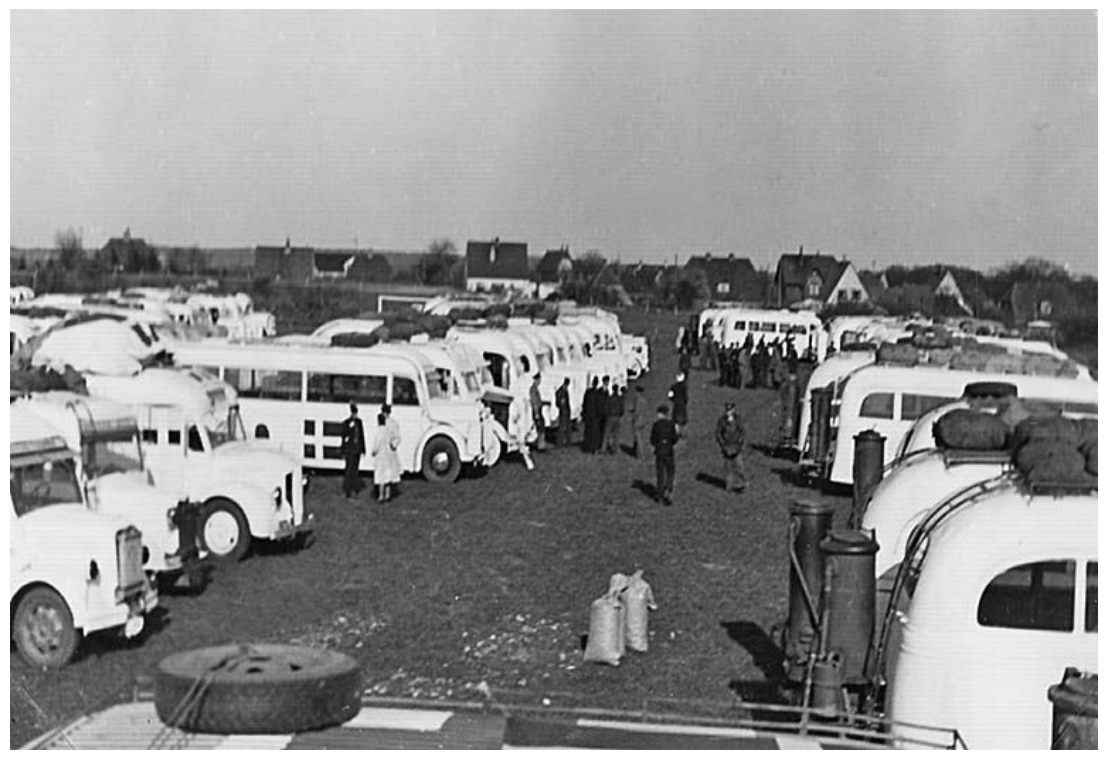

Danske Hvide Busser i Padborg kort for afhentningen af danske og norske fanger $i$ Neuengamme den 20. april 1945. De danske busser, som var gengas-drevne (bemærk generatorerne bag på bilerne), var en broget flåde af private busser, DSB-busser, fiskeeksportbiler osv. De blev samlet $i$ Padborg og malet hvide, før de kørte sydpå. Foto: Frøslevlejrens Museum.

stormagt « under henvisning til den aktuelle svenske flygtninge- og indvandringspolitik, så knytter han an til den almindelige, traditionelle forestilling om den svenske rolle mod slutningen af Anden Verdenskrig.

I den danske grundfortælling om Besættelsen har De Hvide Busser indtaget en helt central rolle. Her anerkender man Bernadottes og Sveriges afgørende rolle i aktionen, men man fremhæver også den danske andel i den. De Hvide Busser har spillet en fremtrædende rolle i fortællingen om den danske modstand mod den tyske besættelsesmagt, og om de lidelser besættelsesmagten påførte det danske folk. De har været et konkret udtryk for, at folk og statsmagt, altså nationen, stod skulder ved skulder i forenet kamp mod det onde, mod tyranniet, og at man ikke svigtede landsmænd i nød. Nogle danske historikere har karakteriseret denne grundfortælling om dansk modstand som en ren konstruktion, som en konsensus-fremstilling, der ikke havde meget med virkeligheden at gøre, men som blot skulle dække over de indre spændinger mellem statsmagt og modstandsbe- 
vægelse. Andre historikere har hævdet, at der faktisk var en fundamental konsensus, altså enighed, i det besatte Danmark, og at netop De Hvide Busser er et godt eksempel på denne konsensus. ${ }^{28}$

Historien bliver konstant nyfortolket, og også stjernestunderne bliver gået kritisk efter i sømmene, sådan som det f.eks. er sket med den danske hjælp til jøderne i oktober 1943. Fortællingen om De Hvide Busser er også blevet underkastet en kritisk revision. Det kulminerede i 2005, da den svenske historiker Ingrid Lomfors udgav bogen Blind Fläck. Minne och glömska kring Svenska röda korsets hjälpinsats $i$ Nazityskland 1945. Her sætter hun især fokus på det særlige afsnit i Neuengamme-lejren, hvor de nordiske fanger blev samlet, et afsnit som kom under direkte administration af Svensk Røde Kors. Med henblik på at skaffe plads til de norske og danske fanger blev hovedbygningen, 'Steinbau', i dette lejrafsnit bogstaveligt talt ryddet for ca. 2.000 dødssyge fanger fra andre lande. Og på den tyske lejrkommandants udtrykkelige forlangende blev disse fanger transporteret til kz-lejren Bergen-Belsen med Hvide Busser. Denne lejr, som lå i nærheden af Hannover, blev af SS frimodigt karakteriseret som en 'Erholungslager', altså en rekreationslejr for syge fanger. Meget få overlevede denne rekreation. Her var altså et punkt $i$ hele undsætningen af de danske og norske fanger, som forekommer at være gået direkte ud over andre fanger. Lomfors' påstand, som er præget af den nutidige forestilling om universelle menneskerettigheder, er, at hjælpen til de danske og norske fanger principielt var racistisk, fordi den ikke omfattede fanger fra andre lande - og at den skete på disses bekostning. Og var det overhovedet moralsk i orden at hjælpe danske og norske fanger, når man ikke kom andre fanger til undsætning? ${ }^{29}$

Af erindringsbogen Sidste Akt står det ret klart, at Bernadotte ikke var blind for de moralske dilemmaer ved visse dele af aktionen. ${ }^{30} \mathrm{Og}$ til hans forsvar kan man fremføre, at han faktisk også fik udvirket, at ca. 10.000 kvindelige fanger fra andre lande (herunder også jødiske fanger) i kz-lejren Ravensbrück blev omfattet af aktionen - fuldstændig som Merete Granzows breve så levende formidler det. Tankegangen bag den danske (og svenske) hjælp til de nordiske kz-fanger var, at man først og fremmest undsætter egne statsborgere og dem, man føler står en nærmest. I dette tilfælde nordiske broderfolk. Denne praksis er stadig gældende: nationalstater undsætter først og fremmest egne statsborgere. Seneste storstilede danske eksempel på denne praksis var, da Danmark for få år siden evakuerede 5.800 danske 
statsborgere samt personer med opholdstilladelse i Danmark, som var blevet fanget i en voldelig konflikt i Libanon. Der var tale om personer af mellemøstlig herkomst, men etniciteten var underordnet, statsborgerskabet eller opholdstilladelsen derimod helt afgørende. På samme vis var der mere end 100 statsløse, fortrinsvis tyske, jøder blandt de ca. 475 jøder, som i oktober 1943 blev deporteret fra Danmark til Theresienstadt, men samtlige deporterede nød rettigheder som danske jøder - og blev af tyskerne behandlet som danske jøder. Dermed undgik også de gaskamrene i Auschwitz. ${ }^{31}$

De tusinder af kvindelige fanger af ikke-nordisk nationalitet, som ankom til Padborg-Kruså området i slutningen af april og begyndelsen af maj 1945, ankom primært med tog. På det tidspunkt var De Hvide Busser stort set ophørt med at køre i Tyskland, ikke mindst på grund af de stadigt hyppigere luftangreb fra allierede fly. ${ }^{32}$ Det sidste 'spøgelsestog' (som togene siden blev benævnt) ankom så sent som den 2. maj med »2.800 kvinder - halvnøgne og hylende af sult. Så snart dørene til vognene blev åbnet, styrtede de ud og kastede sig over alt, hvad der kunne mistænkes for at være spiseligt - kartoffelskræller og græs gik de ikke af vejen for. Egnens befolkning kastede noget brød til dem, som de sloges om som vilde dyr. Det lykkedes at få givet dem noget knækbrød o. lign., som man havde i lejren, og samtidig blev der bestilt mad fra Statshospitalet i Sønderborg «. Sådan beskrives det sidste togs ankomst $\mathrm{i}$ en ellers relativt lidenskabsløs skildring af Socialministeriets virke under Besættelsen fra 1948. ${ }^{33}$

Dette sidste tog kom ganske uanmeldt. Hamborgs kommandant havde samlet kvinderne fra Neuengammes udekommandoer, stoppet dem i godsvogne og sendt toget af sted mod den danske grænse, hvor det ankom efter flere dage, uden at fangerne havde fået hverken vådt eller tørt. De togstammer, som skulle anvendes til den videre transport af kvinderne fra Padborg, kom ikke som lovet den 3. maj om morgenen, angiveligt på grund af modstandsbevægelsens jernbanesabotage. Samtidig blev den allierede flyaktivitet stadig stærkere, f.eks. blev der bombet i nærheden af Flensborg, og man forventede så småt, at også jernbanen i Padborg ville blive udsat for luftangreb. Men til alles lettelse ankom togvognene samme eftermiddag. Kvinderne, som efter opholdet på karantænestationen var blevet mætte og var faldet til ro, kom om bord i toget, og kl. 20 afgik det mod Sverige. ${ }^{34}$ Hermed havde karantænestationen i Padborg, som efter at man forlod Friedrichsruh den 22. april, udgjorde hovedkvarteret for den 


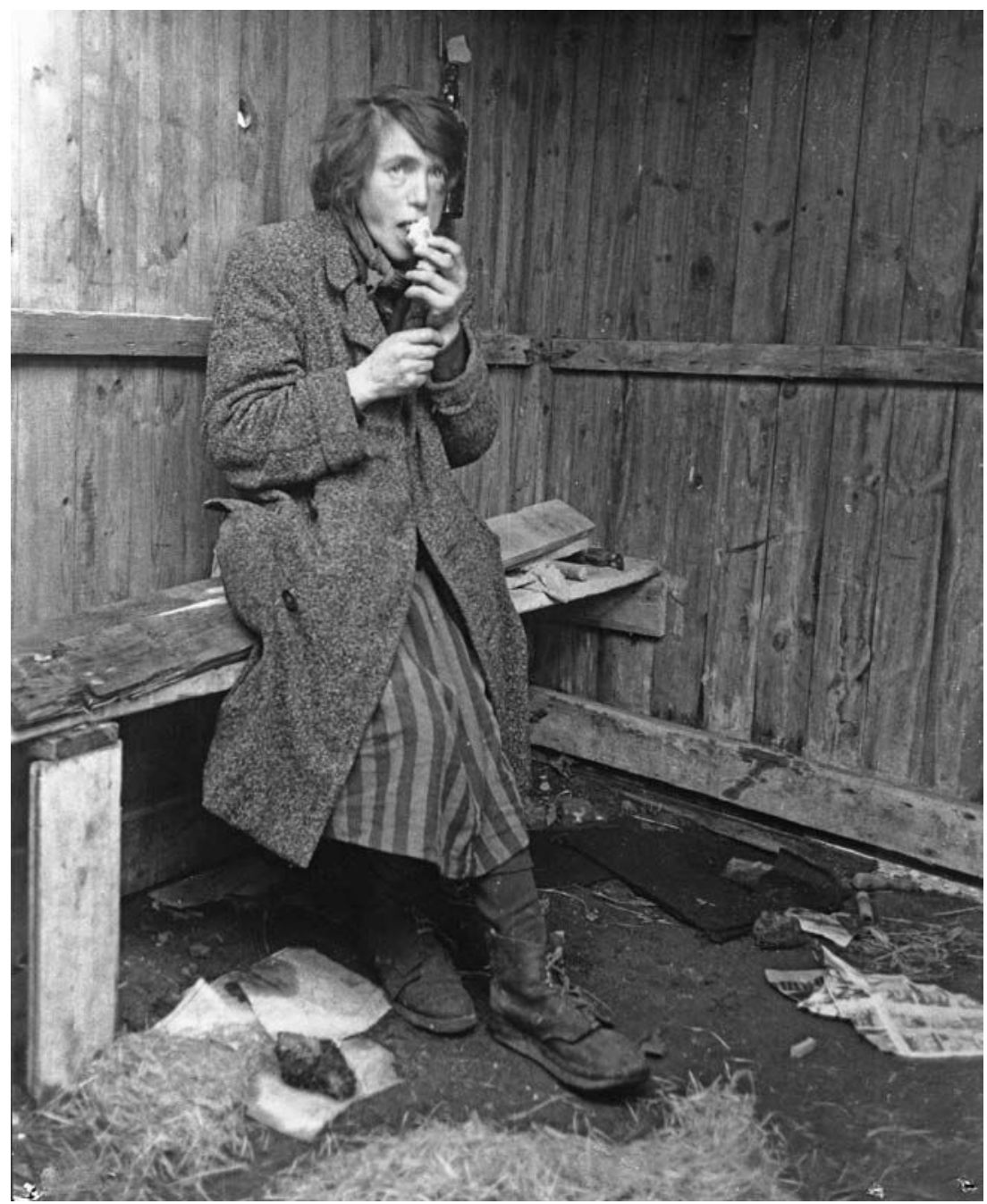

Udhungret koindelig kz-fange, som netop er ankommet til Padborg med 'spøgelsestoget', har fundet sig et sted, hoor hun i fred kan spise sin mad. Foto: Frøslevlejrens Museum.

danske del af evakueringen, udspillet sin rolle. Og den 5. maj om aftenen var karantænestationen i Padborg vært for en sammenkomst med frigivne fanger fra Frøslevlejren. ${ }^{35}$ 


\section{Erindringer om De Hvide Busser}

»De små danske grænsebyer Kruså og Padborg vil efter denne krig stå i en uforglemmelig glans i erindringen ikke blot hos tusinder af danske, men hos endnu flere nordmænd og hos kvinder fra andre besatte lande. Her vendte de tilbage til livet. Her mødte de mennesker igen efter en årelang mishandling.«36

Sådan lyder vurderingen i Befrielsesdage i Sønderjylland fra 1946. Overvurdering af egen betydning forekommer hyppigt i den lokale (og for den sags skyld: nationale) selvforståelse, men her er der uden tvivl belæg for påstanden. Redningen med De Hvide Busser, herunder opholdet i Sønderjylland, blev husket livslangt af fanger fra flere nationer. ${ }^{37}$ Ligeledes må man fastslå, at de forgangne år ikke har udvisket eller reduceret betydningen af Bernadotte-aktionen, skønt (eller måske netop fordi) en eftertid har sat etiske spørgsmålstegn ved aktionen. Sønderjylland og sønderjyder spillede en fremtrædende rolle i aktionen, og det kritiske blik, historikere ud fra et etisk synspunkt, med rette eller urette, har kastet på aktionen som sådan, synes ikke at finde noget belæg, når man anskuer aktionen $i$ et sønderjysk perspektiv. Herom vidner de samtidige breve fra Merete Granzow, der kaster lys over ikke bare aktiviteterne på karantænestationerne i Padborg og Kruså, men også over de motiver, som drev de lokale frivillige. For Merete Granzows vedkommende var hendes kristne livssyn og fædrelandskærlighed stærke drivkræfter, men just hendes patriotisme gjorde, at hun respekterede, ja, beundrede de evakuerede fangers kærlighed til deres lande.

Forhandlingerne på Brundlund Slot i Aabenraa gjorde et blivende indryk hos både værtsparret Refslund Thomsen og den siden så kendte svenske gæst, Folke Bernadotte. Det fremgår umiskendeligt af især Ingeborgs Refslund Thomsens erindringer, men også af en korrespondance mellem Bernadotte og amtmand Refslund Thomsen i 1945-46. Den 10. juli 1945 sendte en attaché Giron fra det svenske Udenrigsministerium i Stockholm taksigelse til værtsparret på Brundlund: 
»Herr Amtmand,

Med de minderige dage i Aabenraa i frisk erindring beder jeg hermed om at oversende en pakke fra greve Bernadotte, som han har overgivet mig til videre befordring. Såvel greven som jeg og alle de andre, der nød godt af amtmandens venlighed og gæstfrihed, som blev os til del i Sønderjylland, og jeg og konsul Schylander, der nu arbejder på samme kontor som jeg, vil endnu engang udtrykke vores varme taknemmelighed [...]. Jeg sender mine varmeste hilsner til Fru Refslund Thomsen og forbliver deres hengivne Attaché Giron. ${ }^{38}$

Refslund Thomsens takkebrev til Giron var ikke mindre kordialt. Amtmanden skriver:

»Skønt hverdagens travlhed i nogen måde altid lægger beslag på en, mindes vi i Aabenraa ofte de svenske herrer, som vi havde den glæde at lære at kende i de bevægede dage før Befrielsen. Min hustru og jeg var meget glade for den hilsen, vi med Deres brev modtog fra greve Folke Bernadotte. Jeg tror, det var min bemærkning til Dem om, at de lokale blades billeder af greven var så forfærdelige, jeg kan takke for det smukke fotografi af greven, som var medindeholdt i forsendelsen.

Skulle Deres vej atter gå over Sønderjylland, beder jeg Dem være forvisset om, at De altid vil være en kær gæst på Brundlund. $\ll^{39}$

Godt en uge senere blev hilsenen til Refslund Thomsens fulgt op af en pakke fra Bernadotte, som blev formidlet af legationsråd BarckHolst fra den svenske ambassade i København. ${ }^{40}$ Hvad pakken indeholdt, fremgår af amtmandens takkebrev til Bernadotte:

»Det var min Hustru og mig en stor Glæde for nogen Tid siden $i$ en forsendelse fra den kongelige svenske ambassade i København at modtage både brev, bog og fotografi. Vi siger Dem hjertelig tak derfor. Bogen [Sidste Akt, dvs. Bernadottes bog om aktionen] har vi læst med den største interesse og både den og Deres smukke billede vil altid være os kære minder over Deres besøg på Brundlund i de begivenhedsrige dage før Befrielsen. ${ }^{41}$ 
De gensidige venligheder var andet end mundsvejr, for da Bernadotte i midten af maj 1946 var på en tjenesterejse til Tyskland, overnattede han med sit følge på Brundlund og nød igen godt af værtsparrets gæstfrihed. Et hovedsamtaleemne under opholdet var selvfølgelig de dramatiske tildragelser umiddelbart før Anden Verdenskrigs afslutning, hvor Brundlund Slot og Sønderjylland var i begivenhedernes centrum. $^{42}$

\section{KILDER}

Utrykte kilder:

Rigsarkivet i Aabenraa.

Amtmandsarkivet for Aabenraa-Sønderborg Amter samt amtmand Refslund Thomsens privatarkiv.

Rigsarkivet $i$ København.

Registranten til 'Udenrigsministeriet Akter ca. 1909-45' samt Frants Hvass' privatarkiv.

\section{LITTERATUR}

Barfod, Jørgen: Redning fra Ragnarok, Årsskrift for Frihedsmuseets venner 1983.

Bech, C.J., Morten Kamphøvener og Kaj Edvard Larsen (red.): Befrielsesdage $i$ Sønderjylland, 1946.

Bernadotte, Folke: Sidste Akt. Mine humanitære Forhandlinger $i$ Tyskland Foraaret 1945 og deres politiske Følger, 1945.

Hæstrup, Jørgen: Til landets bedste. Hovedtræk af departementschefsstyrets virke 1943-45, 1971.

Lidegaard, Bo: Redningsmænd. Skandinaviske aktioner for at redde fanger fra tyske kz-lejre i krigens sidste år, 2015.

Lomfors, Ingrid: Blind Fläck. Minne och glömska kring Svenska röda korsets hjälpinsats $i$ Nazityskland 1945, 2005.

Lund-Jensen, N.P.: »Karantænestationerne i Padborg og Kruså « i Sønderjysk Månedsskrift, nr. 2 1993, s. 23-27.

Mørup, Hans: På fløjen. En sønderjysk Stridsmands erindringer fra kultur- og modstandskamp 1929-1945, 2000.
Froslevlejrens Museum.

'Breve fra Grænsen' af Merete Granzow. De samtidige breve er stencileret og har derfor formentlig cirkuleret i et vist omfang.

Trykte kilder:

Hejmdal

Refslund Thomsen, Ingeborg: Hjemme $i$ Nordslesvig, 1962.

Roesdahl, Harald: »Læge ved De hvide Busser « i Kristensen, Henrik Skov og Inge Adriansen: Als og Sundeved 194045, 2005 (1995), s. 197-217.

Schellenberg, Walther: Den usynlige front. Udgivelsesåret ikke anført, men der er tale om en pocket-udgave af Schellenbergs selvbiografi i dansk oversættelse. Originaludgaven blev udgivet i 1956 af André Deutsch under titlen The Labyrinth. The Memoirs of Hitlers Secret Service Chief.

Skov Kristensen, Henrik: »En politik med rækkevidde. Samarbejdspolitikken og de danske kz-fanger « i Magasin fra det Kongelige Bibliotek nr. 3, 2005, s. 31-46.

Skov Kristensen, Henrik: En station på vej til Helvede. Harreslev banegard og deportationerne fra Froslev til tyske koncentrationslejre, 2010 (2002). 
Skov Kristensen, Henrik, Claus Kofoed og Frank Weber: Bomber over Danmark. Vestallierede luftangreb under 2. Verdenskrig, 2012.

Skov Kristensen, Henrik: »Skandinavienslejren - og de moralske dilemmaer «i Boritz, Mette m.fl. (red.): De Hvide Busser - er du (med)borger?, 2015, s. 7077. [2015a].

Skov Kristensen, Henrik: »Stjernestund eller pagt med Djævelen?« i Boritz, Mette m.fl. (red.): De Hvide Busser er du (med)borger?, 2015, s. 102-107. [2015b].

\section{NOTER}

1. De danske myndigheders bestræbelser på at undsætte danske fanger i Tyskland er første gang behandlet faghistorisk af Jørgen Hæstrup i Til landets bedste. Hovedtræk af departementschefsstyrets virke 1943-45, bd. 2, 1971. Jørgen Barfod beskrev Bernadotte-aktionen i hoved træk i Redning fra ragnarok, Årsskrift for Frihedsmuseets Venner 1983. Henrik Skov Kristensen etablerede i »En politik med rækkevidde. Samarbejdspolitikken og de danske kz-fanger" i Magasin fra det Kongelige Bibliotek nr. 3, september 2005 eksplicit de specielle besættelsespolitiske forhold i det besatte Danmark som en forudsætning for de danske myndigheders undsættelsesbestræbelser. Det samme gjorde siden Hans Sode-Madsen i Reddet fra Hitlers helvede, 2005, som er den første detaljerede monografi på dansk om De Hvide Busser. Monografien, som i 2015 blev genudgivet $i$ en revideret udgave under titlen De Hvide Busser 1941-45. Reddet fra Hitlers helvede, har udpræget fokus på den danske del af aktionen og de danske myndigheders bestræbelser. Der er i en vis forstand tale om en satisfaktion for det daværende danske embedsværk. Et mere internationalt perspektiv får man i Bo Lidegaards Redningsmænd. Skandinaviske aktioner for at redde fanger fra tyske $k z-$
Skov Kristensen, Henrik: »Redningsaktion med moralske dilemmaer «, featureartikel i Jyllands-Posten den 17. april 2015, tillægget 'Viden' s. 6-10.

Skov Kristensen, Henrik: »De Hvide Busser: humanitær triumf eller sort plet«. Essay i Kristeligt Dagblad den 27. april 2015

Sode-Madsen, Hans: De Hvide Busser 1941-45. Reddet fra Hitlers helvede, 2015 (revideret genudgivelse af Reddet fra Hitlers helvede, 2005).

lejre $i$ krigens sidste år, 2015, som følger aktionen, dens tilblivelse og ikke mindst motiverne bag den parallelt $i$ den svenske, den norske, den danske og den tyske lejr.

2. Bech m.fl. 1946. Især bidragene »Hjem over Grænsen", s. 25-40, "Skæbnetoget gennem Danmark " s. 41-58, og »Undervejs med Hjælp« s. 216-239.

3. Bernadotte 1945, s. 71-72.

4. Ibid., s. 81

5. Ibid., s. $81 \mathrm{ff}$, samt Schellenberg [1956], s. $252 \mathrm{ff}$.

6. Bernadotte 1945 , s. 78 .

7. Refslund Thomsen 1962, s. $137 \mathrm{ff}$.

8. Ibid., s. 128-130.

9. De beskrevne rejseaktiviteter og forhandlinger fremgår af både Ingeborg Refslund Thomsens, Folke Bernadottes og Wather Schellenbergs ovennævnte erindringer. Bernadottes skildring fra 1945 kan selvfølgelig sagtens have præget de to senere beretninger.

10. Udenrigsministeriets arkiv i Rigsarkivet indeholder ingen journalsager, som umiddelbart kan sættes i forbindelse med forhandlingerne på Brundlund Slot. Frants Hvass' privatarkiv i Rigsarkivet synes heller ikke at rumme relevante oplysninger om de forhandlinger på Brundlund, som Hvass var en dansk nøglefigur i. 
Forfatteren har endvidere konsulteret Hans Sode-Madsen, som i forbindelse med sin bog har fået nøje kendskab til Udenrigsministeriets og de danske nøglepersoners privatarkiver. Men ifølge Sode-Madsen er han aldrig stødt på arkivalsk materiale, som kaster lys over forhandlingerne på Brundlund Slot. Tænkeligt vil det være muligt at finde arkivalsk materiale af svensk proveniens, men det er ikke forsøgt.

11. Her er Amtmandsarkivet samt Refslund Thomsen privatarkiv, begge beroende i Rigsarkivet i Aabenraa, blevet gennemset. Amtmanden refererede til Indenrigsministeriet, hvis arkiv ikke er blevet frekventeret - ud fra den betragtning, at havde amtmanden udfærdiget en rapport til sine foresatte i Indenrigsministeriet, ville der formodentlig have været en kopi/afskrift i de to nævnte arkiver.

12. Hejmdal 5.5.1945. "Grev Bernadottes store historiske Mission «.

13. Bech m.fl. (red.) 1946, s. 109.

14. Refslund Thomsen 1962, s. 135.

15. Sode-Madsen 2015, s. 290-292.

16. Skov Kristensen 2005, passim. Både Sode-Madsen og Bo Lidegaard har siden gjort det samme synspunkt gældende.

17. Ibid. passim. Uddybende vedr. de enkelte deportationer og disses baggrund, Frøslevlejren samt de forskellige kategorier af deporterede, se Skov Kristensen 2010 (2002), passim.

18. Her efter Skov Kristensen 2005. Mere udførligt beskrevet i Sode-Madsen 2015 samt i Lidegaard 2015.

19. Uddybende vedr. Carl Hammerichs tidlige initiativ til et 'Jyllandskorps', hans norske forbindelser samt de norske initiativer, se Sode-Madsen 2015 , s. $24-29$, s. 200 f. og 224 f. Om den norske del af aktionen, se endvidere Lidegaard 2015 passim.

20. Her efter Skov Kristensen 2005. Uddybende vedr. forhandlingerne mellem danske og tyske myndigheder om hjemtransporter samt forløbet af disse hjemtransporter, se Sode-Madsen 2015, passim.

21. Mørup 2000, s. 413-414. Mørup var blevet deporteret fra Frøslevlejren til
Neuengamme 15.9.1944 og havde overlevet et ophold i den berygtede udekommando Husum-Schwesing. Han havde dog været døden nær som følge af sult og sygdom.

22. De to karantænestationer var ikke oprettet til lejligheden, dvs. til at modtage kz-fanger. De var oprettet på et tidligere tidspunkt med henblik på at modtage danske statsborgere, primært Tysklandsarbejdere, som vendte hjem fra Tyskland til Danmark i en kaossituation. Om etableringen af karantænestationerne $\mathrm{i}$ Padborg og Kruså samt formålet med dem, se Lund-Jensen 1993, s. 23-27. Om stationernes omfang, anvendelse og bemanding i forbindelse med evakueringen af kz-fanger se endvidere Sode-Madsen 2015, s. 198-200 og s. $277 \mathrm{ff}$.

23. 'Breve fra Grænsen' af Merete Granzow. Brevene er stencileret og har derfor formentlig cirkuleret i et vist omfang. De er indleveret til Frøslevlejrens Museum af Ulla Brusch, Rinkenæs, som også har givet de biografiske oplysninger om Merete Granzow. Ifølge disse giftede Merete Granzow sig i 1948 med den 7 år yngre Henryk Sokoler, som var født i Krakow i Polen. Han boede formentlig på dette tidspunkt i Schweiz. Parret bosatte sig i Vordingborg, hvor Merete blev lærer på Marienberg Skole. Hun har udgivet flere lærebøger, blev medlem af Amnesty International og var med til at starte en komité for flygtninge i fare.

24. Der var formentlig tale om såkaldte 'Nacht und Nebel fanger', dvs. fanger, som blev deporteret til et ukendt sted, hvor det ikke var tilladt at korrespondere med de pårørende. De pågældende norske fanger 'forsvandt' bogstaveligt talt. Denne skæbne overgik ingen danske fanger, idet Danmark, modsat Norge, aldrig blev omfattet af Hitlers 'Nacht und Nebel-direktiv«. Det skyldtes de specielle besættelsespolitiske forhold i Danmark.

25. Den tyske besættelse af Danmark 9.4.1940 blev mødt med begejstring af det tyske mindretal i Sønderjyl- 
land, som nu regnede med, at Nordslesvig ville blive genindlemmet i Tyskland.

26. Fra Jens Chr. Hostrups Lærken, 1866.

27. Dette brev, som er dateret 28.4.1945, er i den stencilerede og paginerede udgave af brevsamlingen placeret efter brevet af 1. maj, formentlig af stilistiske årsager.

28. Skov Kristensen 2015b. Endvidere af samme forfatter 27.4.2015.

29. Ibid. Om rydningen af 'Steinbau' (som danske fanger og chauffører direkte medvirkede til), konsekvenserne af rydningen og de moralske dilemmaer i forbindelse med etableringen af det særlige lejrafsnit i Neuengamme, se Skov Kristensen 2015a. Endvidere Skov Kristensen 17.4. 2015. Se endvidere Lidegaard 2015, s. 262-265.

30. Bernadotte 1945, s. 60 .

31. Som note 23.

32. Om luftangrebene på De Hvide Busser og baggrunden for disse, se Skov Kristensen m.fl. 2012, s. 677-682.
33. Sode-Madsen 2015, s. 283.

34. Ibid.

35. Sode-Madsen 2015, s. 279.

36. Bech m.fl. (red.) 1946, s. 28.

37. I forbindelse med den store særudstilling om De Hvide Busser i 2015 på Nationalmuseet kunne det af beretninger, breve og andre tilkendegivelser, som blev lokaliseret og indsamlet, konstateres, at redningen havde gjort et livslangt indtryk på de involverede fanger fra flere nationer.

38. K. Refslund Thomsens privatarkiv, Rigsarkivet i Aabenraa, 734/5 »Breve fra forskellige«. Brev fra attaché Giron til Refslund Thomsen 10.7.1945.

39. Ibid. Brev fra Refslund Thomsen til attaché Giron. Tilsyneladende udateret, men journaliseret 11.8.1945.

40. Ibid. Brev fra Barck-Holst 19.7.1945.

41. Ibid. Brev fra Refslund Thomsen til Folke Bernadotte, tilsyneladende udateret, men journaliseret 11.8.1945.

42. Ibid. Breve fra Bernadotte til Refslund Thomsen 29.4.1946, 20.5.1946 og 27.5.1946.

\section{Zusammenfassung}

Im Laufe der letzten Monate des Zweiten Weltkriegs wurden etwa 17.500 Gefangene durch die sogenannte 'Aktion Bernadotte' aus den deutschen KZ-Lagern befreit. Mit der Aktion sollten vornehmlich dänische und norwegische Gefangene befreit werden, 10.000 der Befreiten kamen jedoch aus anderen Nationen.

Im Allgemeinen wird die Aktion Bernadotte international als schwedisch angesehen, der Artikel weist aber deutlich auf dänische Einschläge hin. So waren es die dänischen 'Weißen Busse', die das sogenannte 'Skandinavienlager' im KZ Neuengamme bei Hamburg evakuierten. Ebenfalls organisierten dänische Behörden die Verpflegung, Quarantänebehandlung und Unterbringung der evakuierten Gefangenen in den Quarantänestationen in Pattburg und Krusau an der deutsch-dänischen Grenze und im Lager Frøslev unmittelbar nördlich der Grenze.

Der südlichste Teil von Sønderjylland spielte damit bei der gesamten Aktion eine hervortretende Rolle, was auch aus den Erinnerungen 
der evakuierten Gefangenen und der 'kollektiven sønderjysken Erinnerung' über die Besatzungsjahre hervorgeht. Außerdem wurde das Schloss Brundlund in Apenrade als Aufenthalts- und Treffpunkt von einigen der Haupt-Akteure in der Aktion Bernadotte benutzt, wie z.B. Folke Bernadotte, Walter Schellenberg und hervortretenden dänischen und schwedischen Beamten.

Schließlich wird in dem Artikel über die Entwicklung der Aktion Bernadotte aus historiographischer Sicht berichtet mit Stellungnahme zu der Kritik, die auf ethischer Grundlage gegen die Aktion erhoben worden war. 